$F$ uel $D$ emand $E$ lasticities for E nergy and

E nvironmental Policies I ndian Sample Survey E vidence

(JE L Codes: $C 2, Q 2, Q 4)$

\title{
Haripriya Gundimeda*
}

Associate Professor

Madras School of Economics

Gandhi Mandapam Road, Chennai - 600025.

Email:hpriyags@yahoo.com

Tel: +91-44-2235 2157/22300304

Fax: +91-44-2235 2155

\section{Gunnar Köhlin ${ }^{1}$}

Associate Professor,

Environmental Economics Unit,

Department of Economics,

Göteborg University.

Ph: + 46-31-773 4426

Fax: +46-31-773 1326

Email: gunnar.kohlin@economics.gu.se

* - Corresponding author.

${ }^{1}$ Financial support of this work from the Swedish International Development Cooperation Agency is gratefully acknowledged. The authors would like to thank Prof. Lennart Flood, Prof. Thomas Sterner, Dr. Fredrik Carlsson, Prof. Olof Johansson Stenman and Dr. Renato Aguilar, all at Department of Economics Göteborg University, for providing very valuable insights. The authors would like to thank the two anonymous reviewers of the Journal, Energy Economics and their constructive suggestions. 
Fuel Demand Elasticities for Energy and

\title{
Environmental Policies Indian Sample Survey Evidence
}

(J EL Codes: C2, Q2, Q4)

\section{Haripriya Gundimeda and Gunnar Köhlin}

\begin{abstract}
India has been running large-scale interventions in the energy sector over the last decades. Still, there is a dearth of reliable and readily available price and income elasticities of demand to base these on, especially for domestic use of traditional fuels. This study uses the linear approximate almost ideal demand system (LA-AIDS) using micro data of more than 100,000 households sampled across India. The LA-AIDS model is expanded by specifying the intercept as a linear function of household characteristics. Marshallian and Hicksian price and expenditure elasticities of demand for four main fuels are estimated for both urban and rural areas by different income groups. These can be used to evaluate recent and current energy policies. The results can also be used for energy projections and carbon dioxide simulations given different growth rates for different segments of the Indian population.
\end{abstract}

\section{WORKING PAPER 9/2006}

June 2006

Price: Rs.35
MADRAS SCHOOL OF ECONOMI CS

Gandhi Mandapam Road

Chennai 600025

\section{India}

Phone: 2230 0304/ 2230 0307/2235 2157

Fax : $22354847 / 22352155$

Email : info@mse.ac.in

Website: www.mse.ac.in
Keywords: LA-AIDS, fuel, India, income, price, elasticities, NSSO data 


\section{Introduction}

The main objective of this paper is to estimate the income and price elasticities of household demand for different kinds of fuels in India. There are a number of motivations for this. Energy is an important necessity for any household. In India the households need to choose not only how much but also which fuel to use. These decisions can have important consequences for the household budget, time allocation and health. They can also lead to negative environmental externalities at local, regional or global level. Price and income elasticities of demand are important for the choice of domestic energy policies. They are also useful in the context of energy policies for greenhouse gas abatement.

Given the policy importance of these elasticities, it is striking that there is such a dearth of reliable and readily available estimates. ${ }^{1}$ Of course, several studies have examined the elasticities of commercial fuels like electricity and LPG in India. However, though some studies have examined the elasticities of fuelwood and also the substitution between fuelwood and commercial fuels, surprisingly few studies have done rigorous analysis. Earlier studies that attempted to analyse fuel demand in India ranged from large-scale macro planning exercises to local household case studies. There was interest in estimates of elasticities for different kinds of fuels as part of macro planning exercise, such as the Energy Survey of India Committee (1965), The Working Group on Energy Policy (1979), The Advisory Board on Energy (1985),

1 This is actually true also in general for developing countries. In an extraordinarily ambitious survey of energy demand elasticities for the developing world, Carol Dahl only found 20 estimates that included biomass. Out of these two were for India, both from the seventies (Dahl, 1994)
The Energy Demand Screening Group (1986), The Rajadhyaksha committee of power sector planning (Gadgil, Sinha and Pillai, 1989) and the Planning Commission (1998). However, the main limitation of all the studies at macro level was that the projections that were made only took into account the aggregates such as population growth rate, increase in GDP, urbanisation and technological advancements. The fundamental problem with these studies is that although macro factors can influence energy consumption patterns indirectly, the actual determinants of household energy consumption are found at the household level. Aggregate fuel demand is made up by the day-to-day decisions at the household level. These decisions are affected by budget and time constraints of the household, their opportunity costs of time, the relative accessibility of fuels (relative prices) as well as social and cultural factors. Given such a perspective, it is obvious that it is e.g. not only GDP growth that matters but also its distribution.

A second group of studies estimated the consumption of biofuels mostly for rural regions (e.g. Joshi et al., 1992). Although surveys of fuelwood consumption at the regional level are an improvement over macro level studies, as the fuel consumption mix is different for different agro-climatic zones, the estimates give only consumption per capita for rural areas. Some studies addressed the urban energy patterns and only some of these studies analysed the determinants of urban energy demand (Ray, 1980; Alam, 1985; Macauley, 1989; Dunkerley et al., 1990, ESMAP, 1992, 2001). Other studies have looked into various other aspects of urban fuel usage. Reddy and Reddy (1983) made a case study of fuelwood use in Bangalore, India. The studies by Dunkerley et al. (1990) and Bowonder et al. (1998) did not estimate the demand for fuelwood or other fuels but looked at consumption and prices of fuelwood for Indian cities in the aggregate. Soussan et al. (1990) 
analysed in a comprehensive study the fuelwood combustion practices in an urban context. Mishra et al. (1995) and Turare (1998) used secondary data to analyse the criteria behind choice of domestic fuel. Alam et al. (1998) too is an investigation into the efficiency aspects of urban domestic fuel choices. Barnes et al. (2002) looked at aggregated energy demand in 46 cities in 13 different countries and is the most comprehensive study of urban fuel in the developing country context to date. A more recent study by Gupta and Köhlin (2006) analysed the preferences for domestic fuel for the Indian city of Kolkata.

A third group of studies examined the consumption of fuelwood in different areas by controlling for income, size of households, landholdings, type of profession, agro-climatic zones, season, accessibility of forests etc. While some studies concentrated on the variation in consumption of fuelwood with different income and landholdings, others studied the consumption in different seasons. The studies are scattered across the country and it is very difficult to make meaningful projections for policy analysis. Some studies are based on more formal household models that have the potential to give the elasticities of interest for policy (see for instance, Amacher, Hyde and J oshee 1993; Pitt 1985; Bluffstone, 1995; Amacher, Hyde and Kanel, 1996; Köhlin and Amacher, 2006; and Heltberg et al., 2000). However, as such studies are very few in number, and only the latter two use data from India, extrapolations cannot be made for the entire country in order to make meaningful policy analyses.

To get reasonably accurate fuel elasticities for a country as big and diverse as India, a lot of time and money need to be spent in obtaining information on fuel use and household characteristics, which is a colossal task. In India, the National Sample Survey Organisation (NSSO) collects information on quantity and expenditure on various commodities for a representative sample of the country. Expenditure and quantity of various fuels are among these commodities. One of the advantages of NSSO data is that even fuelwood collected for free is accounted for by imputing some value on it. In countries like India where majority of the rural people collect fuelwood for free, ignoring these values can result in biased assessments. This paper makes use of such a data set in order to estimate the price and income elasticities of fuelwood. Using a sample that truly reflects the whole population of India has made it possible to overcome some of the weaknesses of the previous approaches. The large sample does not only make it more representative, but it also facilitates disaggregation of the analysis to relevant sub-samples such as different income groups and for urban and rural areas separately. This gives us the opportunity to investigate energy transition in general, and the energy ladder hypothesis in particular, for the country with the highest domestic consumption of bio-energy in the world by estimation of expenditure elasticities of demand. We also analyze the own-price elasticities of different income groups and address the scope for energy substitution by estimation of cross-price elasticities of demand for various fuels.

The estimations are made using the linear approximate almost ideal demand system (LA-AIDS), proposed by Deaton and Muellbauer (1980), on household data for the year 1999. Instead of income we consider the total household expenditure as a proxy. The advantage of the LA-AIDS model is that the demand system is linear in the structural parameters. The LA-AIDS model has been widely used for analysing demand for various commodities in India as well as in other countries. 
In this study we use a two-stage budgeting process to obtain the elasticities of different categories of fuels. In the first stage it is assumed that the household decides how much to spend on fuel and non-fuel commodities and in the second stage they allocate expenditure to different categories of fuel. Such two-stage budgeting has been used earlier to analyse demand for meat (Ealas and Unnevehr, 1988; Gao, Wailes and Cramer, 1996), fish (Cheng and Capps, 1993, Dey, 2000), demand for nondurable commodities (Carpentier and Guyomard, 2001) etc. However no study has used such an approach to estimate fuel elasticities. This study is thus an empirical contribution to the domestic energy literature.

The plan of this paper is as follows: Section 2 presents the two-stage budgeting model. Section 3 lays out the empirical specification. Section 4 discusses the issues in estimation of the model including the methodology to account for zero expenditure. Section 5 describes the data used in the study. Section 6 presents the empirical results and section 6 concludes with the policy implications.

\section{Two-stage budgeting model}

In this paper we use a two-stage budgeting process. Under two-stage budgeting, expenditure decisions on fuels, and all other nonfuel goods, can be represented by a recursive structure where the household first allocate income between fuels and non-fuels and then at a second stage chose its disaggregated fuel expenditures. The theoretical framework for such a two-stage budgeting approach has been well established in the literature. The underlying theoretical model used for our empirical specification is based on the paper Blundell
(1988) and Baker et al. (1989). Here we briefly discuss the theoretical model given in Blundell (1988) in the context of our paper.

Let the households allocate their total expenditure $Y$ to all consumption goods, $x_{1}, \ldots x_{m}$. These consumption goods can then be uniquely allocated to a smaller number of commodity groups represented by commodity vectors $\mathbf{q}_{\mathbf{1}}, \ldots \mathbf{q}_{\mathbf{k}}$. For the purposes of this paper, let us only consider two such commodity vectors, fuel and non-fuel commodity groups. Let these be represented by $\mathbf{q}_{\mathbf{f}}$ and $\mathbf{q}_{\mathbf{n}}$ in the model. Then if utility is weakly separable across these groups, direct utility may be written as

$U\left(x_{1}, \ldots, x_{n}\right)=F\left[U_{f}\left(q_{f}\right), U_{n}\left(q_{n}\right)\right]$

The allocation of expenditure to any $x_{i}$ in $q_{s}$ may then be expressed as

$p_{i} x_{i}=f_{i}\left(\mathbf{p}_{\mathrm{s}}, y_{\mathrm{s}}\right)$ for $i=1, \ldots m$ and $s=f, n$

Disaggregated fuel expenditures thus depend only on relative fuel prices and total fuel expenditure.

This is the second stage of the two stage budgeting rule where $f_{i}$ is related to the utility function, $p_{s}$ is the vector of prices corresponding to $q_{s}$ and $y_{s}$ is the allocation of total expenditure to fuel category $s$. $U(),. F($.$) and U_{s}\left(q_{s}\right)$ are assumed to be concave and continuous and the budget constraint is assumed to be linear. This assumption implies that expenditure equation 2 is linear homogeneous in $\mathbf{p}_{\mathrm{s}}$ and $y_{\mathrm{s}}$ and that the Hicksian or compensated price derivatives are symmetric forming a negative semi-definite Slutsky substitution matrix. 
Once $y_{\mathrm{s}}$ is determined at the first stage, each $q_{\mathrm{s}}$ can be determined without reference to prices outside this group. Assuming homothetic preferences the expenditure equation (2) can be written as

$p_{i} x_{i}=f_{i}\left(\mathbf{p}_{\mathrm{s}}\right) y_{\mathrm{s}}$ for $i=1, \ldots m$ and $s=f, n$

so that each expenditure share $w$ of good $i$ out of group $s$ expenditure $y_{s}$ is given by

$w_{i}^{s}=f_{i}\left(\mathbf{p}_{\mathrm{s}}\right)$

Each expenditure share of good $i$ out of group expenditure $s$ is independent of $y_{s}$ and depends only on within group prices. However (3) can be generalised to allow linear Engel (expenditure/income) curves with non-zero intercepts so that expenditure on good $i$ may be written

$p_{i} x_{i}=a_{i}\left(\mathbf{p}_{\mathrm{s}}\right) p_{i}+f_{i}\left(\mathbf{p}_{\mathrm{s}}\right) y_{s}$

Using Roy's identity, indirect utility takes the form

$V_{s}=G_{s}\left\{\left[y_{s}-a_{s}\left(\mathbf{p}_{\mathrm{s}}\right)\right] / b_{s}\left(\mathbf{p}_{\mathrm{s}}\right)\right]$

Where $a_{s}\left(p_{s}\right)=\sum_{i} p_{i} a_{s i}\left(\mathrm{p}_{s}\right)$. These preferences are known as Gorman Polar Form.

Assuming quasi-homothetic preferences the cost of achieving a level of utility $U_{s}\left(q_{s}\right)$ is

$C\left(\mathbf{p}_{\mathrm{s}}, U_{s}\right)=a\left(\mathbf{p}_{\mathrm{s}}\right)+b_{s}\left(\mathbf{p}_{\mathrm{s}}\right) U_{s}\left(\mathbf{q}_{\mathrm{s}}\right)$
Where $a($.$) and b($.$) are linear homogeneous concave function of prices$ described by the vector of fuel prices $p_{f}$. Differentiating the cost function (7) w.r.t. price and substituting the utility term $U_{s}$ using the identity $C()=.y_{s}$ gives the following Marshallian demands

$x_{i}=a_{i}\left(\mathbf{p}_{s}\right)+f_{i}\left(p_{s}\right) \frac{\left[y_{s}-a\left(p_{s}\right)\right]}{b\left(p_{s}\right)} b_{s}\left(p_{s}\right)$ for $s=f, n$.

where $a_{i}\left(p_{s}\right)$ and $b_{i}\left(p_{s}\right)$ refer to the corresponding price derivatives of $a($.$) and b($.$) respectively. However for empirical analysis we need to$ choose an appropriate functional form. For this paper we choose the Price Independent Generalised Linear (PIGL) functional form suggested by Deaton and Muellbauer (1980). The PIGL has the indirect utility function of the form

$V=G\left\{\left[Y^{\mathfrak{a}}-a(\mathbf{p})^{\mathfrak{a}}\right] /\left[b(\mathbf{p})^{\mathfrak{a}}-a(\mathbf{p})^{\text {á }}\right]\right\}$

Where $a(p)$ and $b(p)$ are linear homogeneous, concave functions of prices. When á $=1$ the indirect utility function become quasi-homothetic and by appropriate choice of $a(p)$ and $b(p)$ can be made to nest the popular Stone-Geary or LES (linear expenditure system) model. However the share equations corresponding to equation (9) are highly nonlinear and to avoid this, Deaton and Muellbauer (1980) work with the logarithmic (PIGLOG) case in which $\propto>0$. Choosing In a(p) to be of a translog form and $\operatorname{lnb}(\mathrm{p})$ to $\pi_{j} p_{j}^{\beta_{j}}+\ln a(\mathrm{p})$ the share model reduces to the Almost Ideal form

$w_{i}=\alpha_{i}+\sum_{i=1}^{n} \gamma_{i j} \ln p_{i}+\beta_{i} \ln (y / a(\mathrm{p}))$ 


\section{Estimation of the model}

$\ln \mathrm{a}(\mathrm{p})=\alpha_{0}+\sum_{i=1}^{n} a_{j} \ln p_{i}+1 / 2 \sum_{i} \sum_{i} \ln (y / a(p))$

where $w_{i}$ is the expenditure share of the $i^{\text {th }}$ commodity, $p_{i}$ is the price of the $i^{\text {th }}$ commodity, $y$ is total expenditure and $p$ is a price index.

The basic demand restrictions are expressed in terms of the model's coefficients

$$
\begin{aligned}
& \sum_{i} \alpha_{i}=1 ; \sum_{i} \gamma_{i j}=0 ; \sum_{i} \beta_{i}=0 \quad \text { (Adding up) } \\
& \sum_{j} \gamma_{i j}=0 \\
& \gamma_{i j}=\gamma_{j i} \square i\left(i^{\prime \prime \prime} j\right)
\end{aligned}
$$

Provided 12, 13 and 14 and 8 hold, equation 10 represents a system of demand functions which add up to total expenditure $\left(\sum \mathrm{w}_{\mathrm{i}}=\right.$ $1)$, are homogeneous of degree zero in prices and total expenditure taken together, and which satisfy Slutsky symmetry. In addition to these, the concavity of the expenditure function or the negative semidefiniteness of the substitution matrix should be satisfied $\left(\gamma_{i j}<0\right.$ for all

i). Changes in real expenditure operate through $\beta_{\mathrm{i}}$ coefficients. These add to zero and are positive for luxuries and negative for necessities.
We estimate the model using SAS (version 9.1). In line with the model presented in the previous section, we assume that the consumer's utility maximization decision can be decomposed into two separate stages, i.e. in the first stage, the total expenditure is allocated over broad groups of goods (here fuel and non-fuel) and in the second stage, the group expenditures are allocated over subgroups and specific commodities. For the first stage we estimate a linear relationship between the budget share of each good and the logarithm of total expenditure. Since the preference parameters are unlikely to be constant across all households we allow for demographic variation in the model. We will thus estimate the following Engel form:

$$
\begin{aligned}
& w_{f}=\alpha_{f}+\beta_{f} \ln X \\
& \text { with } \alpha_{f}=\delta_{0}+\sum_{k=1}^{K} \delta_{k} d_{k}
\end{aligned}
$$

where $\alpha_{\mathrm{fu}} \beta_{\mathrm{fv}} \delta_{0}$ and $\delta_{\mathrm{k}}$ characterise the household preferences. The parameters are estimated by weighted least squares assuming independently and identically distributed (iid) error terms.

The expenditure elasticity of the fuel demand for the average household is given by

$$
e_{f x}=1+\frac{\beta_{f}}{w_{f}} \text {. }
$$


The sign of $\beta_{f}$ determines whether the commodities are necessities/ luxuries. When $\beta_{f}>0$, the commodity is a luxury, if $\beta_{\mathrm{f}}<0$ they are necessities. The coefficients allow assessing the impact of household characteristics on budget share.

In estimation of the demand system we approximate the price index by Stone's index given by

$$
\ln \mathrm{a}\left(P^{s}\right)=\sum_{i} \bar{w}_{i} \ln p_{i}
$$

where $\overline{w_{i}}$ is the mean of the budget share.

This indicates that we estimate the LA/AIDS model which is linearly approximated. This is the main difference between the Almost Ideal Demand System (which uses a price index given by equation 11) and Linear Approximate Almost Ideal demand system (which uses price index given by equation 18 )

As the differences in the demand for different commodities can differ across households due to differences in preferences, we use the demographic translation employed by Pollock and Wales (1981):

$$
\alpha_{i}=\rho_{i 0}+\sum_{s} \rho_{i s} N_{s}
$$

where the $N_{s}$ are the demographic variables $(s=1, \ldots d)$. The above translation assumes that the other parameters of the demand system do not depend upon the socio-demographic variables. The resulting system we finally estimate is

$$
w_{i}=\rho_{i 0}+\sum_{s} \rho_{i s} N_{s}+\sum_{j} \gamma_{i j} \ln p_{j}+\beta_{i} \ln \left(Y / a\left(P^{s}\right)\right)
$$

To preserve the adding up property, eqs (12), (13) and (14) should hold with $\sum_{i} \alpha_{i}=1$ replaced with $\sum_{s} \rho_{i 0}=1 \quad \sum_{i} \rho_{s}=0$

In the second stage, some of the fuel types were not consumed by some of the households. The survey information is usually insufficient to determine whether the zero value represents a household that never consumes the item due to non-preference or because of infrequent consumption. Including only the nonzero observations would result in selection bias if nonpurchasing households behave systematically different from the purchasing households. Hence, we used the Heckmantype sample selectivity correction to account for these nonconsuming households.

The two decisions - whether or not to consume and how much to consume - are thus estimated separately. In the first step, the probability that a given household will purchase a specific good is determined from a probit regression using all available observations. More specifically, in the first step the probability that a given household would purchase the commodity in question is determined using a probit regression as follows:

$$
Z^{*}=h\left(\boldsymbol{x}_{\mathrm{i}}, \boldsymbol{a}\right)+u
$$


where the variable $Z^{*}$ takes the value of 1 if expenditures $\left(w_{i}\right)$ are reported by the $i^{\text {th }}$ household; otherwise it takes the value zero. Vector $x$ represents factors affecting choice of a fuel, vector a represents the corresponding coefficients, and $u_{i}$ is the error term.

This probability is used to compute Inverse Mill's Ratio (MRHi) for each household $h$ and each commodity $i$ as follows

$$
\begin{aligned}
& \lambda=\varphi\left(w_{\mathrm{i}} \varepsilon\right) / \Phi\left(w_{\mathrm{i}} \varepsilon\right)\left(\text { for } Z^{*}=1\right) \\
& \lambda=\varphi\left(w_{\mathrm{i}} \varepsilon\right) / 1-\Phi\left(w_{\mathrm{i}} \varepsilon\right)\left(\text { for } Z^{*}=0\right)
\end{aligned}
$$

Where $\varphi$ represents the standard normal distribution density function evaluated at the value of the probit function. In the second step the inverse Mill's ratio (MRHi) is used as an instrument that incorporates the censored latent variables in the demand equations, which is included as an exogenous variable in the estimation of each demand function. The complete demand model of the allocation of the fuel budget (with symmetry and homogeneity as maintained hypothesis) is estimated using Iterated Seemingly Unrelated Regression (ITSUR) technique proposed by Zellner (1962) so that contemporaneously correlated errors are accounted for and cross-equation parameter restrictions can be imposed (see Greene, 203, pp. 340-350). Because of the adding-up constraint, the dependent variables and the non-stochastic terms in the equations add up to unity for each household, therefore the covariance matrix of residuals is singular. To avoid singularity of the variance-covariance matrix of the disturbance terms one equation has to be dropped and the parameters of this equation can then be calculated using the parameter restrictions of the system. The parameter estimates are invariant to the choice of the deleted equation. The omitted equation is the budget share of electricity in the fuel categories considered for analysis. The adding up restrictions can be checked from equation 4, these ensure that

$$
\sum \mathrm{w}_{\mathrm{i}}=1
$$

The uncompensated own, cross-price and income elasticity of this system are estimated using the formulae suggested by Greene and Olston (1990)

$$
\begin{aligned}
& e_{i i}=\left\lfloor\gamma_{i i}-\beta_{i} w_{i}+\beta_{i}^{2} \ln (\overline{Y)}\rfloor / w_{i}-1\right. \\
& e_{i j}=\left[\gamma_{i j}-\beta_{i} w_{j}+\beta_{i} \beta_{j} \ln (\overline{Y)}]\right. \\
& e_{i f}=\beta_{i} / w_{i}+1 .
\end{aligned}
$$

The elasticities in the first state are multiplied with those of the second stage to obtain integrated elasticities of demand for fuel type w.r.t. total expenditure.

$$
e_{i Y}=e_{f Y} * e_{i f}
$$




\section{Description of data}

The data used for the analysis are taken from a comprehensive survey carried out by the National Sample Survey Organisation on consumption of Important Commodities in India (NSSO, 1999). The data comprises information collected from 68,961 rural households and 50,166 urban households, covering the entire country ( 26 states and 6 union territories). Such surveys are carried out every five years and the present study uses the data from the 55th round (for the year 1998-99). The survey includes detailed information on demographic characteristics, household assets and expenditure on different commodities. An advantage of using the NSSO data is that in addition to providing data on purchased quantities and monetary values, the survey also provides information on the quantities of fuel (and other goods) that were not purchased but acquired through home production or collection. The non-purchased quantities were assigned monetary values by NSSO by evaluating them at (mean) unit-values and then these values are added to household expenditures in the same way as purchased goods.

In order to make the data suitable for analysis, the data were transformed in several ways. The survey data do not classify various households into different income groups. As we are interested in obtaining elasticities for different levels of income, we classified the households into three income groups. For the low-income group we used a policy relevant poverty definition. Based on the consumer expenditure statistics published by the National Sample Survey Organisation, the Planning Commission has estimated state specific poverty lines, using the original state specific poverty lines identified by the Lakdawala Committee and updating them to 1999-2000 prices using the Consumer Price Index for Agricultural Labourers (CPIAL) for rural households and the Consumer Price Index of Industrial Workers (CPIIW) for urban households. The all India average of poverty line based on this is Rs. 328 for rural India and Rs. 454 for urban areas. We used this poverty line to define a low-income group. This cut-off coincided with the lowest quintile. Since there are no similar official cut-offs for middle and higher incomes, we considered the upper quintile as high-income group for symmetry and the rest are classified as middle income. As prices at the household level are reported in the data, unit values for all fuels were imputed as proxies for prices by dividing expenditure on a commodity by the corresponding quantity purchased. ${ }^{2}$ Cross-sectional data typically suffer from limited variation in prices. This sample is less affected by this problem. When the structure of the demand is relatively constant, price variation can be attributed to different supply conditions and be used to identify commodity demand curves. This sample has sufficient variation in supply conditions. Another problem with expenditure surveys is, however, that if a household does not consume a particular type of fuel, there is no data on the price of that fuel for the household. In order to account for the fuel expenditure function and the complete system of fuel share equations, price must be available for all types of fuel for all households. Hence, we used the average price of that particular kind of fuel within the same village/ town as a proxy for missing price. ${ }^{3}$

2 In this case the quantities of different fuels are converted to MJ using World Bank conversion factors that take into consideration both energy content and stove efficiency (Barnes et al, 2002).

3 Several authors' use predicted prices but we do not. Neither are potential biases due to variation in quality of fuels at different prices taken into consideration. 
As can be seen in Table 1, consumption patterns and socioeconomic characteristics differ immensely between poor and rich, rural and urban. The variations in choice of main fuel are further displayed in Figures 1 and 2. As can be seen in Figure 2, there is a marked difference in main fuel use between rich and poor households in urban areas. Poor urban households still use fuelwood as their main fuel while the richer households predominantly use electricity, LPG and to some extent still kerosene. These descriptive statistics does not only support the classical energy ladder hypothesis but is also consistent with the "multiple fuel, or fuel stacking, model" which predicts a cooking strategy that involves more than one fuel at a time (Masera, Saatkamp and Kammen, 2000; Heltberg, 2004, 2005). We can see indications of this, although this data reflects only main fuel, particularly among middle income households that have a significantly more mixed fuel composition. The dramatic differences, not only between rural and urban households, but also between expenditure classes call for the division of the sample into different expenditure groups each for urban and rural areas. The anticipation is that the price and cross-price elasticities of demand, and particularly the expenditure elasticities of demand would differ between these groups. In the analysis we consider fuelwood, kerosene, LPG and electricity. We have not considered other categories because not enough people consume them throughout our sample classifications.

Due to the relatively large proportions of households involved in home production of fuelwood, (see Table 3), demand functions for these fuel categories should ideally be based on a non-separable utility maximizing household model such as those used by Cooke (1998) and Heltberg et al. (2000). Although there is some information at household level, it still has limitations, e.g. in the availability of ancillary resource variables. We therefore consider a reduced form specification that draws as far as possible on the variables provided by the relevant literature, given the limitation of the data set. All relevant fuel prices are of course included. The household characteristics include total household expenditure, household size (expecting economies of scale in fuel consumption), caste (whether backward or forward caste); occupation (whether self employed, for rural households further distinguished to self-employed in agriculture or non-agriculture, agricultural labourer, casual labourer or other professions), as proxies for taste, life-style and opportunity cost of time. We have also included five regional dummies depending on which part of India the household belong to. Table 1 also provides the summary statistics for the corresponding prices, expenditure on fuels and the demographic variables we used in estimating the LA-AIDS model for low, medium and high-income groups.

\section{Empirical results}

The estimations behave overall very well with high significance levels and expected signs. Most variables are significant at the $1 \%$ level throughout the different sub-samples. In Table 2 we present the results from the Engel estimation, corresponding to equation 15 in section 3. Only a few of the explanatory variables are not significant at the $5 \%$ level. The results defy early attempts to explain energy consumption only with population and income growth. ${ }^{4}$ For example, geographical area and forest cover are highly significant factors, naturally affecting the need for (due to climate) and accessibility of various fuels. The profession can also be important, as in the case of the self-employed in non-agriculture in rural areas, who increase the share of total

\footnotetext{
${ }^{4}$ As is done, e.g. in the more simplistic versions of the energy ladder applications, most gap models and also in earlier official fuelwood use statistics by the FAO, due to lack of other data.
} 
expenditures devoted to fuels compared to those who stay in agriculture, with its greater availability of biofuels. We can also see from the negative sign of the coefficient for In expenditure (a proxy for income) that domestic fuel is not a luxury good - as income rises, the share of fuel in total expenditure goes down.

In Tables 4 and 5 we present the probit estimates of the share equations, corresponding to equation 21 in section 3 . They provide evidence of some interesting trends in the fuel choice of Indian households. Caste is a commonly used control variable in Indian demand studies in general and fuelwood collection specifically (see for example Heltberg et al, 2000; Köhlin and Amacher, 2006; Gupta and Köhlin, 2006). Although officially abolished, caste has been shown to still affect both preferences and labor allocation. In Table 4 it is therefore interesting to note that in rural areas the forward caste dummy is significant and positive for the choice of electricity and LPG at $5 \%$ level. Also in urban areas we find forward caste having lower probability of adopting fuelwood and higher probabilities of adoption of electricity and LPG.

The significance for the employment categories indicates the expected differences in life-styles and opportunity costs of time. In rural areas the self-employed (often in agriculture) show evidence of easy access to biomass. This is also true for agricultural laborers, that show significantly higher probability to use fuelwood and kerosene and lower probability to use electricity and LPG. The same pattern can be found among unemployed in urban areas. Household size is expected to increase the probability of not only higher fuel consumption but also more kinds of fuels. Heltberg (2004) found a significant negative effect of household size on Indian households' probability to have no or full fuel switching, indicating that they use multiple fuels. It is therefore interesting to see that in this analysis household size is in general negatively correlated with the probability of adopting electricity and LPG.

The regions also show different adoption patterns. In the case of India this is actually a reflection of policy since electrification and often also LPG and kerosene proliferation is affected by local state policies. It is therefore not surprising to find the East and the South to have significantly higher probability of adoption of electricity and LPG in rural areas. The pattern in urban areas is somewhat different, indicating that such policies could vary between urban and rural areas.

The complete demand system for the allocation of the fuel budget is estimated separately for the three different income groups. In order to test whether such a division of sample into different income groups is warranted we performed a chow test with break points at different income levels. The first break point corresponds to the shift from low income level to middle income and second corresponds to the shift from middle income to high income. The problem is posed as a partitioning of the data into two parts of size $n 1$ and $n 2$. All the observations below the first cut-off point are treated as first group and the observations above the second cut-off point are treated as second group. The null hypothesis to be tested is $\mathrm{HO}=\beta_{1}=\beta_{2}$. This test has $p$ and $n-2 p$ degrees of freedom. The Chow test indicates that the parameters are different for different income levels. Hence the null hypothesis that all the income groups are the same is rejected (see Table 8). 
The results are presented in Tables 6 and 7 for rural and urban households, respectively. The results reiterate a number of the trends that we have already seen in terms of significance levels and expected signs. Household size is correlated with decreasing share of fuelwood and increasing shares of modern fuels such as electricity. Belonging to a forward caste decreases the share of fuelwood, particularly in rural areas. From a forestry point of view it is interesting to note that the forest cover in the region has a positive impact on fuelwood use both in rural and urban areas. Furthermore, it has a significant impact also on the shares of the other fuels. This is consistent with the observation that households are very sensitive to the relative (implicit) price of various fuels and fuel sources (Köhlin and Parks, 2001). Based on the same estimation we will now proceed to the estimation and analysis of price and expenditure elasticities of demand, which is the focus of the paper.

\section{Own-price and cross-price elasticites of demand}

The estimated uncompensated (Marshallian) own-price elasticities for different income groups for urban and rural areas are presented in Table 9. The uncompensated elasticities should be interpreted as conditional elasticities, where it is assumed that the relative price changes within fuel categories would not affect the real expenditure on fuel. We can see from Table 9 that all own-price elasticities have the expected negative sign.

The own-price elasticities for fuelwood are particularly interesting. We find that both rural and urban people seem to be quite responsive to higher costs of fuelwood. These elasticities are typically greater than the elasticities found in a number of smaller samples in
India and elsewhere (Hyde and Köhlin, 2000). It supports the conventional wisdom that households easily respond to higher prices (market or shadow) through demand management or substitution to other fuels. However, this implies that households are affected by higher fuelwood prices either through increased fuel costs, since alternatives higher up the ladder are more expensive, or by adaptation to inferior fuels, or simply by reducing their fuel consumption. Two developments in Indian local forest management could give rise to local fuelwood scarcity. One is the recent interest in using forests for carbon sequestration rather than using them to meet the demand from local communities. Secondly, there is now evidence that local protection of natural forests, e.g. by J oint Forest Management, in many cases have a negative impact on the availability of fuelwood for poor households and women. For a recent review of such evidence, see Cooke et al. (2006).

The compensated price elasticities are given in Table 10. For normal goods the Hicksian own price elasticities are in absolute terms smaller than the Marshallian ones. The Hicksian values in Table 10 give the most accurate picture of cross-price substitution since they provide a measure of substitution effects net of income effects. These crossprice elasticities have some potential important policy implications given the highly regulated Indian energy sector. The policies over the last decades have meant implicit or explicit subsidies of fuelwood (through plantation programs), coal (government owned mining sector with regulated prices), kerosene (subsidized rations to households), electricity, particularly to agriculture, and LPG, although the latter is being deregulated. At the time of the data collection in 1999 the kerosene subsidy was around 52 percent of the reference price, that of cooking coal 42 percent, LPG 32 percent, and electricity 64 percent for 
household use (Bussolo and O'Connor, 2001). There are at least two environmental arguments to decrease fuelwood use through subsidies of a close substitute. The first one is the classical, but seldom substantiated, claim that fuelwood collection leads to deforestation. The second is the evidence that low-grade fuels lead to indoor air pollution that is associated with a number of diseases (Kammen, 1995; Smith, 2005; Heltberg, 2005).

The cross-price elasticities reported in Table 10 can be used to analyze the impact of such policies on urban and rural households at different levels of income. Few studies have looked at cross-price elasticities when analysing energy demand in developing countries. In cases where they have been estimated and found to be significant, the elasticities are small (Ishiguro and Akimaya, 1995). It is therefore not surprising to see that all but one of the cross-price elasticities are inelastic. Even so, the table indicates overall high significance in these elasticities and thus potential for policy impact. The cross-price elasticity of demand for fuelwood with respect to kerosene price ranges from 0.43 for middle income urban households to 0.71 for low income rural households. The same elasticity with respect to electricity is highest, 0.65 , for low income urban households. The greatest impact on fuelwood demand, however, comes from LPG in rural areas, particularly low income households that have a cross-price elasticity of 0.84 . It should also be noted again that the energy prices are adjusted for efficiency. Since fuelwood has the lowest efficiency, this means that these crossprice elasticities under-estimate the actual quantity changes. It should also be remembered that the availability and reliability of supplies is probably as important as price for the choice of fuel, as shown by data collected in Kolkata (Gupta and Köhlin, 2006). Given the significant and relatively responsive cross-price elasticities, combined with substantial subsidies, we can expect that the past energy policies have actually had a major impact on domestic fuel choices in India.

\section{Expenditure elasticities of demand}

Income has been the single most important explanatory factor in the literature on the choice of domestic fuel over the last decades (Arnold, Köhlin, Persson, 2006). It is also the basis for the energy ladder model and although this model has been elaborated lately (Masera et al, 2000; Heltberg, 2004), income, or its proxy expenditure, remains as the most important variable in explaining fuel demand. This can also be understood from Figures 1 and 2 that show the dramatic change in major domestic fuel choice (i.e. not considering multiple fuels) in rural and urban areas as per capita expenditure increases. In rural areas solid fuels such as dung, fuelwood and charcoal decrease from almost $80 \%$ among the poorest households to $20 \%$ among the richest. The drop is even more dramatic in urban areas where less than $10 \%$ of the richest use these fuels as their main fuel while the proportion among the poorest is the same as in rural areas. As expected electricity and LPG use increase with increased expenditure while kerosene and biogas are transitional fuels.

Expenditure elasticities of demand for the different fuel categories are given in Table 11. The elasticities obtained from the AIDS model are with respect to the expenditures on fuels only. In order to get the relevant "total" or "integrated" expenditure elasticities, the 
estimated elasticities have to be multiplied with the Engel elasticities obtained in step 1. The Engel elasticities are all highly significant and are positive and below one throughout the sample. This means that fuel, as a category, should be seen as a necessity.

The integrated expenditure elasticities of demand for fuelwood are consistently very high compared to previous estimates (Hyde and Köhlin, 2000; Broadhead et al, 2003). It indicates that fuelwood use will be pervasive in India for a long time. The highest elasticity of all is actually for fuelwood - for low income urban households - for whom fuelwood has an elasticity above 1 . The lowest elasticities, around 0.4 , are for electricity in rural areas. One reason for this could be the lack of availability that would constrain the responsiveness of demand to higher income. The elasticities presented in Table 11 also indicate non-linearities over expenditure classes. In order to pursue this aspect further the expenditure elasticities for more disaggregated expenditure groups are presented in Figures 3 and 4. In Figure 3 we can see that poor rural households, who most likely are energy constrained, have comparatively high expenditure elasticities. For the medium expenditure group the elasticities are very stable while they drop sharply for the households with expenditures above 750 Rupees per capita and month. The picture is similar for urban households although the final drop in elasticities comes at a much higher level of expenditure.

\section{Conclusions and policy implications}

Domestic energy is a necessity. Given its importance for household welfare, public investments and environmental considerations it is surprising that not more formal analyses have been carried out for developing countries to analyse income, own-price and cross-price elasticities of demand for a full set of domestic energy sources, including fuelwood. The proliferation of national sample surveys might help to address this gap. In this paper we have shown that the Indian National Sample Survey Organization data, that include quantities and values of self-collected fuelwood, can be used for this purpose. We have also shown that further insights can be sought by disaggregating the data into relevant sub-samples, in this case in urban and rural samples, which were sub-divided into expenditure classes.

The results from this exercise can be used in a number of ways, depending on the policy objective in mind. For a country like India, with a tradition of implicit and explicit government interventions that affect the prices of domestic fuels, the impact of such interventions on demand can be analyzed based on own- and cross-price elasticities of demand. Similarly, if the desired policy objective is transition towards clean fuels (like LPG and electricity) due to the health impacts or local and global pollution, then these elasticities can prove useful in identifying the most cost-efficient policy.

Another area of application is simulation for energy planning. As was indicated in the introduction, there have been a number of energy planning exercises in India over the last decades. Such exercises could be made more realistic and accurate it they were based on the kind of analysis provided in this paper. Domestic energy demand in India is not only of domestic interest today. Given the population of India, this has become a global concern. For example, global greenhouse 
gas emission models would benefit from such estimates. The same holds for simulations of GHG emissions given implementation of a global carbon tax.

The analysis has already given rise to a wealth of empirical information. The probit analysis highlighted the rural - urban differences in adoption of modern fuels and indicated that scheduled caste settlements in rural areas might be deprived of electricity with potentially alarming health implications as a result. We also identified significant regional differences in adoption. The estimation of the full LA-AIDS model gave further evidence of these differences and reminded us also of the significance that resources such as forests have in shaping domestic energy demand. Finally, the expenditure elasticities informed us that dependence on fuelwood will continue for a long time and that when we simulate future demand we will need to be careful in considering not only population and income growth, but also the distribution of this growth.

There are still a number of improvements that could be made to this approach. Cross-sectional sample surveys are notoriously difficult to use in order to estimate price elasticities, primarily due to the lack of variation in price and the potential confounding with quality effects (Deaton, 1990). For future fuel related estimations, panel data analysis is probably worth attempting combined with more flexible functional forms. Sample surveys combined with collection of fuel prices would of course be ideal. The estimation would probably also be greatly improved if it were possible to combine the household expenditure data with exogenous information regarding accessibility of different sources of fuels. A geographical information system would be useful to structure the physical information for such analysis. Such rich data sets could also be used for much more disaggregated analysis than what has been made here.

\section{References}

Abdulai, A., D.K. Jain and A.K. Sharma (1999), Household Food Demand Analysis in India, Journal of Agricultural Economics, 50, 316-327.

Advisory Board on Energy (1985), Towards a Perspective on Energy Demand and Supply in India in 2004/05, (Government of India Printing Office, New Delhi.).

Alam, M. (1985), Fuelwood use in the cities of the developing countries: two case studies from India, Natural Resources Forum, 9, 205-213.

Alam, M., Sathaye, J., and Barnes, D. (1998), Urban Household Energy Use in India: Efficiency and Policy Implications, Energy Policy 26(11), 885-891.

Amacher, G., W. Hyde and K.R. Kanel (1996), Household Fuelwood Demand and Supply in Nepal's Tarai and Mid-Hills: Choice between Cash outlays and Labor Opportunity, World Development, 24(11), 1725-36.

Amacher, G., W. Hyde, and B. Joshee (1993), Joint Production and Consumption in Traditional Households: Fuelwood and Crop Residues in Two Districts of Nepal, Journal of Development Studies, 30, 206-225.

Michael Arnold, Gunnar Köhlin, Reidar Persson and Gillian Shepherd, Fuelwood Revisited: What has changed in the last decade?, with CIFOR Occasional Paper No. 39, 2003.

Baker, P., Blundell, R. W. and Micklewright, J. (1989), Modelling household energy expenditures using micro-data, Economic Journal, 99, pp. 720-738. 
Barnes, D. F., K. Krutilla, and W.F. Hyde. (2002), The Urban EnergyTransition-Energy, Poverty, and the Environment: Two Decades of Research. Forthcoming book volume.

Bluffstone, R. (1995), The effect of labour markets on deforestation in developing countries under open access: an example for rural Nepal, J ournal of Environmental Economics and Management, 29(1), 42-63.

Blundell, Richard (1988), Consumer Behaviour: Theory and Empirical Evidence - A survey, Economic J ournal, Vol. 98, No. 389, 16-65.

Bowonder, B. S. S. R. Prasad, and N. V. M. Unni (1988), Dynamics of fuelwood prices in India: policy implications, World Development, Vol. 16 (10): 1213-1229.

Broadhead, J., J. Bahdon and A. Whiteman (2003), Past trends and future prospects for the utilisation of wood for energy, in Köhlin, G. (ed) Fuelwood - Crisis or Balance?, Göteborg University.

Bussolo, M. and D. O'Connor (2001), Clearing the air in India: The Economics of climate policy with ancillary benefits, Technical Paper 182, OECD, Development Centre, Paris.

Byrne, P.J., O. Capps J r. and A. Saha (1996), Analysis of Food-AwayFrom-Home Expenditure Patterns for U.S. Households, 19821989, American J ournal of Agricultural Economics, 78, 614-627.

Carpentier, A. and H. Guyomard (2001), Unconditional Elasticities in Two-Stage Demand Systems: an Approximate Solution, American Journal of Agricultural Economics, 83, 222-229.

Cheng, H-T. and O. Capps, J r. (1993), Demand Analysis of Fresh and Frozen Finfish and Shellfish in the United States, American Journal of Agricultural Economics, 103, 908-915.
Cooke, P. (1998), Intrahousehold Labour Allocation Responses to Environmental Good Scarcity: a Case Study of Nepal, Economic Development and Cultural Change, 46,807-830.

Cooke, P., G. Köhlin and W.F. Hyde, Fuelwood (2006), forests and community management - evidence from household studies, submitted to Environment and Development Economics.

Dahl, C. (1994), A Survey of Energy Demand Elasticities for the developing World, Journal of Energy and Development, 18(1), 1-45.

Deaton, A. and J. Muellbauer (1980), An Almost I deal Demand System, American Economic Review, 70, 312-26.

Deaton, A. S. (1990), Price Elasticities from Survey Data: Extension and Indonesian Results, Journal of Econometrics, 44, 281-309.

Dey, M.M. (2000), Analysis of Demand for Fish in Bangladesh, Aquaculture Economics and Management, 4, 63-79.

Dunkerley, J., M. Macauley, M. Naimuddin and P. C. Agarwal (1990), Consumption of Fuelwood and Other Household Cooking Fuels in Indian cities, Energy Policy,18(1), 92-99.

Ealas, J.S. and L.J. Unnevehr (1988), Demand for Beef and Chicken Products: Separability and Structural change, American J ournal of Agricultural Economics, 70, 521-532.

Energy Demand Screening Group (1986), Report of the Energy Demand Screening Group, GOI/EDSG, (Planning Commission, New Delhi,)

Energy Survey of India Committee (1965), Report of the Energy Survey of India Committee, GOI/ESI, New Delhi, Planning Commission. 
ESMAP (Energy Sector Management Assistance Programme) (2001), Energy Strategies for Rural India: Evidence from Six States (draft), J oint UNDP/World Bank Programme, Washington DC.

ESMAP/UNDP (1992), Strategy for Household Energy, The World Bank, Washington, DC.

Gadgil, M., M. Sinha and J. Pillai (1989), India: A Biomass Budget Final Report of the Study Group on Fuelwood and Fodder, Centre for Ecological Sciences, Indian Institute of Sciences, Bangalore.

Gao, X. M., E.J. Wailes and G.L. Cramer (1996), A Two-Stage Rural Household Demand Analysis: Micro data Evidence from J iangsu Province, China, American Journal of Agricultural Economics, 78, 604-613.

GOI, (Government of India) (1993), Report of the Expert Group on Estimation of Proportion and Number of Poor, Perspective Planning Division, Planning Commission, Government of India.

Greene, W. H. (2003), Econometric Analysis: International Evidence, Prentice Hall, New Jersey.

Green, R. and J.M. Alston (1990), Elasticities in AIDS models. American Journal of Agricultural Economics, 72: 442-445.

Gupta, G. and G. Köhlin (2006), Preferences in urban domestic fuel demand: the case of Kolkata, India, forthcoming Ecological Economics.

Heckman, J.J . (1979), Sample Selection bias as a specification error, Econometrica, 46, 1251-1271.
Heltberg, R. (2004), Fuel switching: evidence from eight developing countries, Energy Economics, 26, 869-887.

Heltberg, R. (2005), Factors determining household fuel choice in Guatemala, Environment and Development Economics, 10, 337-361.

Heltberg, R., C. Arndt and N. U. Sekhar (2000), Fuelwood Consumption and Forest Degradation: A Household Model for Domestic Energy Substitution in Rural India, Land Economics, 76(2), 213-232.

Hyde, W.F. and G. Köhlin (2000), Social Forestry reconsidered, Silva Fennica, 34(3), 285-314.

Ishiguro, M., and T. Akimaya (1995), Energy Demand in Five Major Asian Developing Countries, World Bank Discussion Papers 277, World Bank, Washington D.C.

J oshi, V., C. S. Sinha, M. Karuppaswamy, K. K. Srivastava and P. B. Singh, (1992), Rural Energy Data Base, TERI, New Delhi.

Kammen, D.M. (1995), Cook stoves for the Developing World, Scientific American, 273, 72-75.

Köhlin, G. and G. S. Amacher (2006), Welfare Implications of Community Forest Plantations in Developing Countries: The Orissa Social Forestry Project, American Journal of Agricultural Economics, 87(4): 855-869.

Köhlin, G. and P. Parks (2001), Spatial Variability and Incentives to Harvest: Deforestation and Fuelwood Collection in South Asia, Land Economics 77(2): 206-218.

Leser, C.E. (1963), Forms of Engel functions. Econometrica, 31, 694-703. 
Macauley, M. (1989), Fuelwood use in urban areas: a case study in Raipur, India, Energy Journal, 10, 157-80.

Masera, O.R., S.D. Saatkamp and D.M. Kammen (2000), From Linear Fuel Switching to Multiple Cooking Strategies: A Critique and Alternative to the Energy Ladder Model, World Development, 28(12), 2083-2103.

NCA (1976), Report of the National Commission on Agriculture, Ministry of Agriculture and Irrigation, New Delhi.

NSSO (1997), Consumption of some Important Commodities in India, Report No, 404, National Sample Survey Organisation, New Delhi.

NSSO (1999), Consumption of some important commodities in India, Report No. 461, National sample Survey Organisation, New Delhi.

Pitt, M.M. (1985), Equity, externalities and energy subsidies - the case of kerosene in Indonesia. Journal of Development Economics, 17, 201-217.

Planning Commission (1998), Sectoral Energy Demand in the Ninth Plan and the Perspective Period up to 2011/12, Planning commission, New Delhi.

Pollock, R. A. and T. J. Wales (1981), Demographic Variables in Demand Analysis, Econometrica, 49, 1533-58.

Ray, R. (1980), Analysis of a Time Series of Household Expenditure Surveys for India, Review of Economics and Statistics, 62 (4), 595-602.
Reddy, A.K. N, and B. S. Reddy (1983), Energy in a stratified society: case study of firewood in Bangalore, Economic and Political weekly, New Delhi, 8th October.

Saha, A., Capps, O. and Byrne, P.J . (1997), Calculating marginal effects in dichotomous-continuous models, Applied Economics Letters, 4, 181-185.

Smith, K.R. (2005), Indoor air pollution: update on the impacts of household solid fuels, Environment Matters, World Bank, Washington DC, 14-16.

Soussan, J., P. O'Keefe, and B. Munslow (1990), Urban fuelwood: challenges and dilemmas, Energy Policy 18: 572-582

Turare C Autom (1998), Energy Options for Households in India (in Household Energy: The Urban Dimension), Boiling Point NO 41 , Intermediate Technology Development Group, Wales.

WGEP (1979), Report of the Working Group on Energy Policy, Planning Commission, Government of India, New Delhi.

Working, H. (1943), Statistical laws of family expenditure, Journal of the American Statistical Association, 33, 43-56.

Zellner, A. (1962), An efficient method of estimating seemingly unrelated regressions and tests for aggregation bias, Journal of the American Statistical Association, 57, 348-368. 
Table 1: Mean statistics divided into rural, urban and expenditure categories

\begin{tabular}{|c|c|c|c|c|c|c|c|c|c|c|c|c|}
\hline & \multicolumn{6}{|c|}{ Rural averages } & \multicolumn{6}{|c|}{ Urban averages } \\
\hline & Mean & $S D$ & Mean & $S D$ & Mean & $S D$ & Mean & $S D$ & Mean & $S D$ & Mean & $S D$ \\
\hline Income group & \multicolumn{2}{|c|}{ Low } & \multicolumn{2}{|c|}{ Medium } & \multicolumn{2}{|c|}{ High } & \multicolumn{2}{|c|}{ Low } & \multicolumn{2}{|c|}{ Medium } & \multicolumn{2}{|c|}{\begin{tabular}{|l|} 
High \\
\end{tabular}} \\
\hline $\begin{array}{l}\text { Number of } \\
\text { observations }\end{array}$ & 12296 & & 43923 & & 12742 & & 7430 & & 30937 & & 8810 & \\
\hline Household size & 5.98 & 2.52 & 5.26 & 2.64 & 4.23 & 2.47 & 5.92 & 2.37 & 4.61 & 2.19 & 3.18 & 1.79 \\
\hline $\begin{array}{l}\text { Share of fue } \\
\text { total expend }\end{array}$ & 0.38 & 0.20 & 0.32 & 0.19 & 0.23 & 0.16 & 0.43 & 0.22 & 0.33 & 0.19 & 0.18 & 0.13 \\
\hline $\begin{array}{l}\text { Price of fuel wood } \\
\text { (Rs/Mega Joule) }\end{array}$ & 0.11 & 0.11 & 0.16 & 0.36 & 0.20 & 0.54 & 0.15 & 0.097 & 0.16 & 0.12 & 0.16 & 0.12 \\
\hline $\begin{array}{l}\text { Price of Kerosene } \\
\text { (Rs/MJ) }\end{array}$ & 0.16 & 0.03 & 0.16 & 0.04 & 0.16 & 0.06 & 0.17 & 0.03 & 0.18 & 0.03 & 0.18 & 0.03 \\
\hline Price of LPG & 0.53 & 0.45 & 0.52 & 0.50 & 0.49 & 0.45 & 0.40 & 0.12 & 0.40 & 0.15 & 0.40 & 0.16 \\
\hline Price of electricity & 0.41 & 0.13 & 0.44 & 0.17 & 0.46 & 0.21 & 0.73 & 2.36 & 0.61 & 1.54 & 0.55 & 1.19 \\
\hline $\begin{array}{l}\text { Expenditur } \\
\text { of Fuelwoo }\end{array}$ & 0.67 & 0.25 & 0.59 & 0.28 & 0.38 & 0.32 & 0.39 & 0.34 & 0.14 & 0.25 & 0.03 & 0.12 \\
\hline $\begin{array}{l}\text { Expenditure s } \\
\text { of kerosene }\end{array}$ & 0.23 & 0.23 & 0.21 & 0.22 & 0.16 & 0.21 & 0.29 & 0.28 & 0.22 & 0.28 & 0.09 & 0.20 \\
\hline $\begin{array}{l}\text { Expenditure sh } \\
\text { of Electricity }\end{array}$ & .10 & 0.17 & 0.17 & 0.22 & 0.30 & 0.24 & 0.26 & 0.25 & 0.38 & 0.23 & 0.50 & 0.24 \\
\hline $\begin{array}{l}\text { Expenditure share } \\
\text { of LPG }\end{array}$ & 0.00 & 0.04 & 0.03 & 0.12 & 0.16 & 0.25 & 0.06 & 0.19 & 0.27 & 0.29 & 0.38 & 0.25 \\
\hline $\begin{array}{l}\text { Household monthly } \\
\text { per capita expenditure }\end{array}$ & 270 & 43 & 504 & 119 & 1184 & 649 & 360 & 67 & 830 & 261 & 2138 & 1159 \\
\hline & & & & & & & & & & & & \\
\hline Profession 1 & 0.13 & 0.34 & 0.15 & 0.35 & 0.169 & 0.375 & 0.41 & 0.49 & 0.37 & 0.48 & 0.28 & 0.45 \\
\hline Profession 2 & 0.44 & 0.50 & 0.25 & 0.44 & \begin{tabular}{|l|}
0.07 \\
\end{tabular} & 0.26 & 0.20 & 0.40 & 0.43 & 0.49 & 0.56 & 0.50 \\
\hline Profession 3 & 0.08 & 0.28 & 0.08 & 0.27 & 0.06 & 0.24 & 0.32 & 0.47 & 0.11 & 0.31 & 0.02 & 0.12 \\
\hline Profession 4 & 0.28 & 0.45 & 0.40 & 0.32 & 0.42 & 0.49 & 0.00 & 0.03 & 0.00 & 0.03 & 0.00 & 0.03 \\
\hline Forward caste & 0.25 & 0.43 & 0.33 & 0.47 & 0.52 & 0.50 & 0.32 & 0.46 & 0.53 & 0.50 & 0.70 & 0.46 \\
\hline Scheduled caste/tribe & 0.13 & 0.33 & 0.18 & 0.39 & 0.09 & 0.28 & 0.24 & 0.43 & 0.12 & 0.32 & 0.06 & 0.23 \\
\hline Southern region & 0.09 & 0.28 & 0.14 & 0.35 & 0.26 & 0.44 & 0.27 & 0.45 & 0.27 & 0.45 & 0.23 & 0.42 \\
\hline Northern region & 0.17 & 0.37 & 0.22 & 0.41 & 0.40 & 0.49 & 0.34 & 0.47 & 0.33 & 0.47 & 0.32 & 0.47 \\
\hline Eastern Region & 0.29 & 0.45 & 0.33 & 0.47 & 0.12 & 0.32 & 0.13 & 0.33 & 0.18 & 0.38 & 0.17 & 0.38 \\
\hline Western Region & 0.34 & 0.47 & 0.10 & 0.30 & 0.10 & 0.30 & 0.21 & 0.41 & 0.13 & 0.34 & 0.20 & 0.40 \\
\hline North-eastern & 0.09 & 0.28 & 0.21 & 0.41 & 0.12 & 0.33 & 0.04 & 0.21 & 0.09 & 0.29 & 0.08 & 0.27 \\
\hline $\begin{array}{l}\text { Percentage of } \\
\text { forest area }\end{array}$ & 20 & & 14 & 35 & 21 & 22 & 17 & 12 & 19 & 19 & 19 & 18 \\
\hline
\end{tabular}

Profession 1: Rural: Self-employed (in non-agriculture/agriculture); Urban: Selfemployed.

Profession 2: Rural: Agricultural labour; Urban: Regular wage/salary earner.

Profession 3: Rural: Other labour; Urban: Casual labour.

Profession 4: For Rural and Urban Other Professions/unemployed
Table 2: Engel estimates of share of expenditures on fuels

\begin{tabular}{|l|c|c|r|r|r|r|}
\hline & \multicolumn{3}{|c|}{ Rural } & \multicolumn{3}{c|}{ Urban } \\
\hline $\begin{array}{l}\text { Dependent variable: } \\
\text { share of fuel in } \\
\text { total expenditure }\left(w_{f}\right)\end{array}$ & Low & Middle & High & Low & Middle & \multicolumn{1}{c|}{ High } \\
\hline Intercept & $0.862^{*}$ & $0.486^{*}$ & $0.705^{*}$ & 0.092 & $0.743^{*}$ & $0.475^{*}$ \\
& $(14.35)$ & $(22.70)$ & $(43.22)$ & $(1.25)$ & $(39.91)$ & $(33.8)$ \\
\hline Household size & $0.031^{*}$ & $0.033^{*}$ & $0.031^{*}$ & $0.042^{*}$ & $0.050^{*}$ & $0.036^{*}$ \\
& $(46.57)$ & $(111.1)$ & $(70.16)$ & $(42.9)$ & $(13.3)$ & $(75.7)$ \\
\hline Southern region & $0.028^{*}$ & $0.043^{*}$ & $0.0256^{*}$ & $0.103^{*}$ & $0.022^{*}$ & -0.004 \\
& $(14.19)$ & $(18.29)$ & $(6.36)$ & $(15.7)$ & $(8.24)$ & $(-1.39)$ \\
\hline Northern region & $0.025^{*}$ & $0.042^{*}$ & $0.022^{*}$ & $0.117^{*}$ & $0.032^{*}$ & 0.006 \\
& $(6.16)$ & $(19.01)$ & $(5.62)$ & $(18.9)$ & $(12.46)$ & $(2.61)$ \\
\hline Eastern region & $0.053^{*}$ & $0.063^{*}$ & $0.029^{*}$ & $0.109^{*}$ & $0.032^{*}$ & $0.020^{*}$ \\
& $(8.22)$ & $(21.7)$ & $(6.39)$ & $(13.81)$ & $(11.47)$ & $(7.24)$ \\
\hline Western Region & $-0.0422^{*}$ & $-0.0653^{*}$ & $-0.0651^{*}$ & $-0.078^{*}$ & $-0.038^{*}$ & 0.022 \\
& $(4.98)$ & $(18.2)$ & $(10.40)$ & $(5.12)$ & $(7.86)$ & $(-2.80)$ \\
\hline Profession 1 & 0.005 & $0.021^{*}$ & $0.009^{*}$ & 0.027 & 0.005 & $0.027^{*}$ \\
& $(0.97)$ & $(9.78)$ & $(3.23)$ & $(2.92)$ & $(1.80)$ & $(9.64)$ \\
\hline Profession 2 & 0.030 & -0.004 & $-0.027^{*}$ & 0.029 & $-0.009^{*}$ & 0.002 \\
& $(2.99)$ & $(-1.87)$ & $(-6.11)$ & $(2.99)$ & $(3.29)$ & $(0.81)$ \\
\hline Profession 3 & $0.036^{*}$ & $0.023^{*}$ & $-0.017^{*}$ & 0.004 & $-0.022^{*}$ & $-0.0252^{*}$ \\
& $(5.58)$ & $(7.84)$ & $(-3.75)$ & $(0.41)$ & $(-6.06)$ & $(-3.12)$ \\
\hline Forest & $0.002^{*}$ & $0.008^{*}$ & $0.0003^{*}$ & $0.008^{*}$ & $-0.0006^{*}$ & 0.00004 \\
& $(10.10)$ & $(12.47)$ & $(4.21)$ & $(3.33)$ & $(-9.25)$ & $(0.50)$ \\
\hline Ln Expenditure & $-0.128^{*}$ & $-0.066^{*}$ & $-0.092^{*}$ & -0.006 & $-0.099^{*}$ & $-0.057^{*}$ \\
& $(-12.67)$ & $(-19.54)$ & $(-41.6)$ & $(-0.49)$ & $(-37.20)$ & $(-32.3)$ \\
\hline Forward caste & $0.022^{*}$ & $0.021^{*}$ & $0.009^{*}$ & $0.021^{*}$ & $0.025^{*}$ & $0.011^{*}$ \\
& $(4.79)$ & $(4.79)$ & $(4.33)$ & $(4.46)$ & $(15.19)$ & $(5.35)$ \\
\hline R-square & 0.19 & 0.27 & 0.40 & 026 & 0.46 & 0.43 \\
\hline
\end{tabular}

Note: The figures in the parentheses are t-ratios \& ' $*$ ' denote the $5 \%$ significance level

Table 3: Households classified by source of fuel wood for different income groups (rural and urban)

\begin{tabular}{|l|r|r|r|r|r|r|}
\hline \multicolumn{1}{|c|}{ Sector } & \multicolumn{3}{c|}{ Rural } & \multicolumn{3}{c|}{ Urban } \\
\hline Source of fuel wood & \multicolumn{1}{c|}{ Low } & Medium & \multicolumn{1}{c|}{ High } & Low & Medium & High \\
\hline Only Purchase & 2296 & 9688 & 2402 & 3246 & 5972 & 378 \\
\hline Only Home grown stock & 1466 & 9596 & 3659 & 190 & 972 & 181 \\
\hline Both purchase and home grown & 274 & 1320 & 359 & 99 & 250 & 22 \\
\hline Only free collection & 7607 & 16993 & 2404 & 1162 & 1167 & 50 \\
\hline Others & 434 & 1229 & 208 & 70 & 160 & 20 \\
\hline Not using Fuel wood & 1388 & 5092 & 3708 & 2662 & 22416 & 8159 \\
\hline
\end{tabular}


Table 4: Probit estimates of share equations for rural areas

\begin{tabular}{|c|c|c|c|c|c|c|c|c|c|c|c|c|}
\hline RURAL & Choic & & & Choic & ce of & cosene & Choice & of & ctricity & & hoice & \\
\hline $\begin{array}{l}\text { variable } \\
\text { if fuel sl }\end{array}$ & Inc $=1$ & Inc $=2$ & Inc $=3$ & Inc $=1$ & Inc $=\mathbf{2}$ & Inc $=3$ & $I n c=1$ & Inc $=2$ & Inc $=3$ & Inc $=1$ & Inc $=2$ & Inc $=$ \\
\hline Intercept & & & & & & & & & $\left\{\begin{array}{c}-3,97 * 7 \\
(-13,31)\end{array}\right.$ & \begin{tabular}{|c|}
$-9,34^{*}$ \\
$(-3.36)$
\end{tabular} & $\mid \begin{array}{l}-13,272 \\
-(-34,82)\end{array}$ & \\
\hline Forwar & & & & & & & & & $\begin{array}{r}0,32^{*} \\
(11,13)\end{array}$ & $\begin{array}{l}0,48^{*} \\
(3,34)\end{array}$ & & \begin{tabular}{|c|}
$0,49 *$ \\
$(18,20)$
\end{tabular} \\
\hline Profession & & & & & & & & & \begin{tabular}{|c|}
$-0,30^{*}$ \\
$(-8,98)$
\end{tabular} & $\begin{array}{r}-0,41 \\
(-1,96)\end{array}$ & & \begin{tabular}{|c|}
$-0,57 *$ \\
$(-19,99)$
\end{tabular} \\
\hline Profession 2 & & & & & & & & & \begin{tabular}{|c}
$-0,77^{*}$ \\
$(-14,16)$ \\
\end{tabular} & \begin{tabular}{|c|c|}
$-0,87$ \\
$(-3,65)$ \\
\end{tabular} & $\mid \begin{array}{c}-1,21 \\
(-23,52\end{array}$ & \begin{tabular}{|c|c|}
$-1,08 *$ \\
$(-15,57)$ \\
\end{tabular} \\
\hline & & $\begin{array}{c}0,40^{*} \\
(10,68)\end{array}$ & \begin{tabular}{|l|l}
$0,27 * *$ \\
$(5,08)$
\end{tabular} & & & & & & \begin{tabular}{|c|}
$-0,50^{*}$ \\
$(-8,60)$
\end{tabular} & $\begin{array}{r}-0,57 \\
(-1,84)\end{array}$ & $\begin{array}{c}-0,711^{2} \\
(-14,08)\end{array}$ & $\begin{array}{c}-1,05^{-} \\
(-16,00)\end{array}$ \\
\hline & & & $\begin{array}{c}0,12^{*} \\
(13,38)\end{array}$ & & & $\begin{array}{r}0,11^{*} \\
(10,63)\end{array}$ & & $\begin{array}{c}-0,10^{*} \\
(-21,61)\end{array}$ & \begin{tabular}{|c|c}
$-0,04 *$ \\
$(-4,44)$ \\
\end{tabular} & $\begin{array}{r}-0,07 \\
(-1,20)\end{array}$ & $\begin{array}{c}-0,16 \\
-(-19,89) \\
\end{array}$ & $\begin{array}{c}-0,10^{*} \\
(-12,64) \\
\end{array}$ \\
\hline & & & $\begin{array}{r}-0,10 \\
(-1,65)\end{array}$ & & & & $\begin{array}{c}0,77^{*} \\
(10,60)\end{array}$ & & $\begin{array}{l}0,31^{*} \\
(4,95)\end{array}$ & $\begin{array}{r}0,82 \\
(2,20)\end{array}$ & ,62) & $\begin{array}{r}0,16 \\
(2,71)\end{array}$ \\
\hline & & & & & & & & & \begin{tabular}{|c|c}
$-0,21^{*}$ \\
$(-3,87)$
\end{tabular} & \begin{tabular}{r|}
0,31 \\
$(0,92)$
\end{tabular} & 0,06 & $\begin{array}{r}0,03 \\
(0,49)\end{array}$ \\
\hline & & & \begin{tabular}{|l}
$-0,49 *$ \\
$(-7,89)$
\end{tabular} & & & \begin{tabular}{|r}
$-0,13$ \\
$(-1,72)$
\end{tabular} & & \begin{tabular}{|r|r}
$0,88^{*}$ \\
$(27,69)$
\end{tabular} & $\begin{array}{l}0,45^{*} \\
(6,22)\end{array}$ & $\begin{array}{r}0,57 \\
(1,54)\end{array}$ & $(7,75)$ & $\begin{array}{l}0,33^{*} \\
(5,04)\end{array}$ \\
\hline Western & & $\begin{array}{r}-0,80^{*} \\
(-22,11)\end{array}$ & \begin{tabular}{|l}
$-0,27 *$ \\
$(-4,46)$
\end{tabular} & & & & & $\begin{array}{c}-0,94^{*} \\
(-35,05)\end{array}$ & $\begin{array}{c}-1,07 \\
(-17,35)\end{array}$ & $-4,04$ & $\mid \begin{array}{r}-0,78 * \\
(-0,98)\end{array}$ & \begin{tabular}{|c|}
$-0,54^{*}$ \\
$(-8,13)$
\end{tabular} \\
\hline Price fu & & \begin{tabular}{|c|c}
$-0,11^{*}$ \\
$(-7,93)$
\end{tabular} & $\begin{array}{r}0,00 \\
(-0,17)\end{array}$ & & & & & & \begin{tabular}{|c|}
$0,21^{*}$ \\
$(9,80)$ \\
\end{tabular} & $(-1,06)$ & & \begin{tabular}{|c|c|}
, $08^{*}$ \\
$(3,99)$
\end{tabular} \\
\hline Price kt & & & & & & & & & & $\begin{array}{r}0,31 \\
(0,69) \\
\end{array}$ & & $\begin{array}{r}-0,16 \\
(-2,93) \\
\end{array}$ \\
\hline Price elt & & & & & & & & & & $\begin{array}{r}-0,07 \\
(-0,25)\end{array}$ & & $\begin{array}{c}-0,32^{*} \\
(-8,47)\end{array}$ \\
\hline Price LI & & & $\begin{array}{c}-0,01 \\
(-0,42)\end{array}$ & & & & & $\begin{array}{c}-0,17 * \\
(-11,33)\end{array}$ & \begin{tabular}{|c|}
$-0,29 *$ \\
$(-8,22)$ \\
\end{tabular} & $\begin{array}{r}-0,31 \\
(-1,32)\end{array}$ & $\mid \begin{array}{r}-0,04 \\
(-1,30)\end{array}$ & $\begin{array}{r}-0,04 \\
(-0,95)\end{array}$ \\
\hline & & & $\begin{array}{l}-0,30^{*} \\
(-9,34)\end{array}$ & & & & $\begin{array}{r}0,74^{*} \\
(13,21)\end{array}$ & $\begin{array}{r}1,033^{*} \\
(42,87)\end{array}$ & $(14,47)$ & $\begin{array}{r}0,91 \\
(2,27)\end{array}$ & $(32,45)$ & $\begin{array}{r}1,11^{*} \\
(30,93)\end{array}$ \\
\hline
\end{tabular}

Note: The figures in the parentheses are t-ratios \& ' $*$ ' denote the $5 \%$ significance level
Table 5: Probit estimates of share equations for (Urban areas)

\begin{tabular}{|c|c|c|c|c|c|c|c|c|c|c|c|c|}
\hline \multirow{2}{*}{$\begin{array}{l}\text { URBAN } \\
\text { Dependent } \\
\text { variable }=1 \\
\text { if fuel share }>0\end{array}$} & \multicolumn{3}{|c|}{ Choice of Fuelwood } & \multicolumn{3}{|c|}{ Choice of Kerosene } & \multicolumn{3}{|c|}{ Choice of Electricity } & \multicolumn{3}{|c|}{ Choice of LPG } \\
\hline & Inc $=1$ & Inc $=2$ & Inc $=3$ & Inc $=1$ & Inc $=2$ & Inc $=3$ & Inc $=1$ & Inc $=2$ & Inc $=3$ & Inc $=1$ & Inc $=2$ & $\operatorname{Inc}=3$ \\
\hline Intercept & $\begin{array}{r}-0.34 \\
(0.77)\end{array}$ & $\begin{array}{c}3.31^{*} \\
(16.92)\end{array}$ & $\begin{array}{c}-2.23 * \\
(4.58)\end{array}$ & \begin{tabular}{|l|l}
$-2.42 *$ \\
$(-4.08)$
\end{tabular} & $\begin{array}{c}6.31^{*} \\
(31.91)\end{array}$ & \begin{tabular}{|r}
$3.79^{*}$ \\
$(11.30)$
\end{tabular} & \begin{tabular}{|l}
$-6.84 *$ \\
$(-15.59)$
\end{tabular} & $\mid \begin{array}{r}-5.07 * \\
(-21.76)\end{array}$ & \begin{tabular}{|c|}
$-3.51^{*}$ \\
$(-6.02)$
\end{tabular} & $=\begin{array}{l}-9.47^{*} \\
(-12.05)\end{array}$ & $\mid \begin{array}{r}-14.17^{*} \\
(64.92)\end{array}$ & $\begin{array}{l}-10.41^{*} \\
(21.65)\end{array}$ \\
\hline Forward caste & $\begin{array}{c}-0.19^{*} \\
(5.59)\end{array}$ & 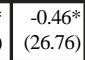 & \begin{tabular}{|l|l}
$-0.45^{*}$ \\
$(9.47)$
\end{tabular} & $\begin{array}{r}-0.15 \\
(-2.79)\end{array}$ & \begin{tabular}{|c}
$-0.41^{*}$ \\
$(23.48)$
\end{tabular} & \begin{tabular}{|c|}
$-0.45^{*}$ \\
$(13.40)$
\end{tabular} & $\begin{array}{l}0.29 * \\
(8.19)\end{array}$ & $\begin{array}{l}0.20^{*} \\
(9.88)\end{array}$ & $\begin{array}{r}0.13 \\
(2.20)\end{array}$ & $\begin{array}{l}0.16^{*} \\
(3.52)\end{array}$ & $\begin{array}{c}0.46^{*} \\
(27.01)\end{array}$ & \begin{tabular}{|c|c}
$0.49^{*}$ \\
$(11.91)$
\end{tabular} \\
\hline $\begin{array}{l}\text { Profession } 1 \\
\end{array}$ & $\begin{array}{r}0.18 \\
(2.73)\end{array}$ & $\begin{array}{l}0.15^{*} \\
(4.89)\end{array}$ & $\begin{array}{r}0.04 \\
(0.59)\end{array}$ & $\begin{array}{l}0.42^{*} \\
(4.55)\end{array}$ & $\begin{array}{l}0.22^{*} \\
(7.25)\end{array}$ & $\begin{array}{r}0.10 \\
(2.05)\end{array}$ & \begin{tabular}{|c|}
$-0.22^{*}$ \\
$(-3.22)$
\end{tabular} & $\begin{array}{r}-0.11 \\
(-2.88)\end{array}$ & $\begin{array}{r}0.04 \\
(0.51)\end{array}$ & $\begin{array}{r}-0.26 \\
(-2.98)\end{array}$ & $\begin{array}{l}-0.27^{*} \\
(-8.90)\end{array}$ & $\begin{array}{r}-0.14 \\
(-2.25)\end{array}$ \\
\hline $\begin{array}{l}\text { Profession } 2 \\
\end{array}$ & $\begin{array}{c}-0.22 * \\
(3.18)\end{array}$ & $\begin{array}{c}-0.18^{*} \\
(-5.95)\end{array}$ & \begin{tabular}{|l|l}
$-0.21^{*}$ \\
$(3.19)$
\end{tabular} & $\begin{array}{r}0.07 \\
(0.75)\end{array}$ & $\begin{array}{l}0.10^{*} \\
(3.49)\end{array}$ & $\begin{array}{r}0.07 \\
(1.49)\end{array}$ & $\begin{array}{c}-0.05 \\
(-0.70)\end{array}$ & $\begin{array}{r}-0.10 \\
(-2.73) \\
\end{array}$ & $\begin{array}{r}-0.04 \\
(-0.62) \\
\end{array}$ & $\begin{array}{r}0.01 \\
(0.08)\end{array}$ & $\begin{array}{r}-0.19 \\
(-6.36) \\
\end{array}$ & $\begin{array}{r}-0.10 \\
(-1.90) \\
\end{array}$ \\
\hline Profession3 & $\begin{array}{l}0.46^{*} \\
(7.01)\end{array}$ & $\left(\begin{array}{c}0.62^{*} \\
(17.50)\end{array}\right.$ & \begin{tabular}{|c|c} 
& $0.63^{*}$ \\
$(4.67)$
\end{tabular} & $\begin{array}{l}0.57 * \\
(6.19)\end{array}$ & $\begin{array}{r}0.78^{*} \\
(18.14)\end{array}$ & $\begin{array}{l}0.73^{*} \\
(5.90)\end{array}$ & $\begin{array}{c}-0.54^{*} \\
(-8.01)\end{array}$ & $\begin{array}{c}-0.52^{*} \\
(-12.79)\end{array}$ & \begin{tabular}{|c}
$-0.53^{*}$ \\
$(-3.60)$
\end{tabular} & $\begin{array}{c}-0.81^{*} \\
(-8.17)\end{array}$ & $\begin{array}{c}-1.05^{*} \\
(25.75)\end{array}$ & $\begin{array}{c}-1.78^{*} \\
(10.57)\end{array}$ \\
\hline Household size & $\begin{array}{l}0.07 * \\
(6.06)\end{array}$ & $\begin{array}{c}0.19^{* *} \\
(32.58)\end{array}$ & $\begin{array}{l}0.06^{*} \\
(3.45)\end{array}$ & \begin{tabular}{|r|r|}
-0.04 \\
$(-2.87)$
\end{tabular} & $\begin{array}{r}0.17^{*} \\
(27.67)\end{array}$ & $\begin{array}{r}0.14^{*} \\
(10.22)\end{array}$ & $\begin{array}{c}-0.07 * \\
(-6.87)\end{array}$ & \begin{tabular}{|c|}
$-0.04 *$ \\
$(-5.79)$
\end{tabular} & $\begin{array}{r}0.07 \\
(2.46)\end{array}$ & $\begin{array}{l}-0.14^{*} \\
(-7.89)\end{array}$ & \begin{tabular}{|c|c|}
$-0.19^{*}$ \\
$(-33.00)$
\end{tabular} & $\begin{array}{r}0.05 \\
(2.28)\end{array}$ \\
\hline Southern region & $\begin{array}{r}0.10 \\
(1.27)\end{array}$ & $\begin{array}{l}-0.22^{*} \\
(-7.03)\end{array}$ & $\begin{array}{ll}-0.24^{*} \\
(-3.18)\end{array}$ & $\begin{array}{r}-0.21 \\
(-1.45)\end{array}$ & $\begin{array}{c}-0.32^{*} \\
(-8.48)\end{array}$ & $\begin{array}{l}-0.60^{*} \\
(-9.54)\end{array}$ & $\begin{array}{r}0.7^{*} \\
(8.64)\end{array}$ & $\begin{array}{r}0.53^{*} \\
(13.13)\end{array}$ & $\begin{array}{l}0.81^{*} \\
(7.65)\end{array}$ & $\begin{array}{l}-0.43^{*} \\
(-4.30)\end{array}$ & $\begin{array}{c}-0.14^{*} \\
(-4.25)\end{array}$ & \begin{tabular}{|c|c|}
$-0.29^{*}$ \\
$(-3.66)$
\end{tabular} \\
\hline Northern region & \begin{tabular}{|c|}
$-0.34^{*}$ \\
$(-4.11)$
\end{tabular} & $\begin{array}{c}-0.76^{*} \\
(-21.35)\end{array}$ & $\left(\begin{array}{l}-1.00^{*} \\
(-10.75)\end{array}\right.$ & \begin{tabular}{|c}
$-0.59^{*}$ \\
$(-3.95)$
\end{tabular} & $\begin{array}{r}-0.88^{*} \\
(-21.90)\end{array}$ & $\begin{array}{l}-1.20^{*} \\
(-17.08)\end{array}$ & $\begin{array}{l}0.41^{*} \\
(5.04)\end{array}$ & \begin{tabular}{|c}
$0.13^{*}$ \\
$(3.42)$
\end{tabular} & $\begin{array}{c}-0.02 \\
(-0.24)\end{array}$ & $\begin{array}{r}-0.28 \\
(-2.28)\end{array}$ & $\begin{array}{r}0.10 \\
(2.87)\end{array}$ & $\begin{array}{r}0.12 \\
(1.35)\end{array}$ \\
\hline Eastern region & \begin{tabular}{|l|l}
$-0.57^{*}$ \\
$(-6.34)$
\end{tabular} & $\begin{array}{c}-1.02^{*} \\
(-26.05)\end{array}$ & $\left\{\begin{array}{c}-1.23^{*} \\
(-11.38)\end{array}\right.$ & $\begin{array}{r}-0.42 \\
(-2.62)\end{array}$ & $\begin{array}{c}-0.73^{*} \\
(-16.75)\end{array}$ & $\begin{array}{c}-1.02^{*} \\
(-13.64)\end{array}$ & $\begin{array}{l}0.76^{*} \\
(8.36)\end{array}$ & $\begin{array}{l}0.45^{*} \\
(9.57)\end{array}$ & \begin{tabular}{|c}
$0.43^{*}$ \\
$(3.68)$
\end{tabular} & $\begin{array}{r}-0.05 \\
(-0.49)\end{array}$ & $\begin{array}{r}0.09 \\
(2.34)\end{array}$ & $\begin{array}{r}-0.21 \\
(-2.27)\end{array}$ \\
\hline Western region & $\begin{array}{r}-0.13 \\
(-1.56)\end{array}$ & $\mid \begin{array}{c}-0.54^{*} \\
(-15.00)\end{array}$ & \begin{tabular}{|l|l}
$-0.71^{*}$ \\
$(-7.12)$
\end{tabular} & \begin{tabular}{|r}
0.45 \\
$(2.78)$
\end{tabular} & $\begin{array}{c}0.33^{*} \\
(7.82)\end{array}$ & $\begin{array}{l}0.28^{*} \\
(4.12)\end{array}$ & $\begin{array}{r}-0.09 \\
(-1.14)\end{array}$ & \begin{tabular}{|c|c|}
$-0.23^{*}$ \\
$(-6.01)$
\end{tabular} & $\begin{array}{r}0.12 \\
(1.32)\end{array}$ & $\begin{array}{l}-0.97^{*} \\
(-8.48)\end{array}$ & $\begin{array}{r}-0.44^{*} \\
(-12.35)\end{array}$ & $\begin{array}{l}-0.38^{*} \\
(-4.42)\end{array}$ \\
\hline Price fuelwood & $\begin{array}{r}0.06 \\
(1.84)\end{array}$ & \begin{tabular}{|c|c}
5 & 0.01 \\
$(0.97)$ &
\end{tabular} & \begin{tabular}{|c|r|}
-0.11 \\
$(-2.39)$
\end{tabular} & $\begin{array}{r}0.07 \\
(1.31)\end{array}$ & $\begin{array}{l}0.10^{*} \\
(6.20)\end{array}$ & $\begin{array}{r}0.01 \\
(0.45)\end{array}$ & $\begin{array}{r}0.09 \\
(2.56)\end{array}$ & $\begin{array}{r}-0.02 \\
(-1.28)\end{array}$ & $\begin{array}{r}0.01 \\
(0.21)\end{array}$ & $\begin{array}{r}0.11 \\
(2.56)\end{array}$ & $\begin{array}{r}0.01 \\
(1.01)\end{array}$ & $\begin{array}{r}-0.04 \\
(-1.10)\end{array}$ \\
\hline Price kerosene & $\begin{array}{r}-1.52^{*} \\
(-11.46)\end{array}$ & \begin{tabular}{|l|l}
-1.34 \\
$(-24.77)$
\end{tabular} & $\begin{array}{ll}-0.59^{*} \\
(-4.62)\end{array}$ & $\begin{array}{r}-0.23 \\
(-1.20)\end{array}$ & \begin{tabular}{|c|c}
$-0.42^{*}$ \\
$(-8.08)$
\end{tabular} & $\begin{array}{c}-0.78^{*} \\
(-8.52) \\
\end{array}$ & $\begin{array}{c}-0.81^{*} \\
(-6.13)\end{array}$ & $\begin{array}{r}-0.14 \\
(-2.29)\end{array}$ & \begin{tabular}{|c|c|}
$-0.45^{*}$ \\
$(-3.41)$
\end{tabular} & $\begin{array}{r}0.07 \\
(0.45)\end{array}$ & $\begin{array}{c}-0.26^{*} \\
(-4.88)\end{array}$ & $\begin{array}{r}-0.23 \\
(-1.97)\end{array}$ \\
\hline Price electricity & $\begin{array}{l}0.22^{*} \\
(5.38)\end{array}$ & \begin{tabular}{|c|c}
$0.21^{*}$ \\
$(10.49)$
\end{tabular} & \begin{tabular}{|l|l}
$0.18^{*}$ \\
$(3.01)$
\end{tabular} & \begin{tabular}{|c}
$0.26^{*}$ \\
$(3.63)$ \\
\end{tabular} & $\begin{array}{r}0.27^{*} \\
(11.74)\end{array}$ & $\begin{array}{c}0.26^{*} \\
(6.03)\end{array}$ & $\begin{array}{l}-0.15^{*} \\
(-4.29)\end{array}$ & \begin{tabular}{|r}
0 \\
$(-0.03)$
\end{tabular} & $\begin{array}{r}-0.09 \\
(-1.4)\end{array}$ & $\begin{array}{r}-0.04 \\
(-0.88)\end{array}$ & $\begin{array}{r}0.00 \\
(0.16)\end{array}$ & \begin{tabular}{|c|c}
$-0.17^{*}$ \\
$(-3.05)$
\end{tabular} \\
\hline $\begin{array}{l}\text { Price LPG } \\
\end{array}$ & $\begin{array}{r}-0.20 \\
(-2.81)\end{array}$ & \begin{tabular}{c|c}
$0.17^{* *}$ \\
$(-4.80)$
\end{tabular} & $\begin{array}{c}-0.27 \\
(-2.89)\end{array}$ & $\begin{array}{r}0.00 \\
(-0.01)\end{array}$ & $\begin{array}{l}-0.16^{*} \\
(-3.85)\end{array}$ & \begin{tabular}{|c}
$-0.21 *$ \\
$(-3.14)$
\end{tabular} & $\begin{array}{l}0.23 * \\
(3.27)\end{array}$ & $\begin{array}{r}0.03 \\
(0.92)\end{array}$ & $\begin{array}{r}-0.23 \\
(-2.25)\end{array}$ & $\begin{array}{r}0.08 \\
(0.75)\end{array}$ & $\begin{array}{l}0.28^{*} \\
(7.43)\end{array}$ & $\begin{array}{l}0.33^{*} \\
(3.59)\end{array}$ \\
\hline Ln expenditure & $\begin{array}{c}-0.28^{*} \\
(-5.04)\end{array}$ & \begin{tabular}{|c|c}
$-0.80^{*}$ \\
$(-32.43)$
\end{tabular} & $\left(\begin{array}{c}0.01 \\
(0.26)\end{array}\right.$ & $\begin{array}{l}0.56^{*} \\
(7.48)\end{array}$ & $\begin{array}{r}-0.78 \\
(-32.11)^{*}\end{array}$ & $\begin{array}{c}-0.56^{2} \\
(-14.39)\end{array}$ & $\begin{array}{r}0.84^{*} \\
(15.13)\end{array}$ & $\begin{array}{r}0.75^{*} \\
(25.46)\end{array}$ & $\begin{array}{l}0.42^{*} \\
(5.84)\end{array}$ & $\left\{\begin{array}{r}1.31^{*} \\
(12.43)\end{array}\right.$ & $\begin{array}{r}1.85^{*} \\
(68.49)\end{array}$ & $\begin{array}{r}1.27^{*} \\
(21.78)\end{array}$ \\
\hline
\end{tabular}

Note: The figures in the parentheses are t-ratios \& ' $*$ ' denote the $5 \%$ significance level 


\section{Table 6: Estimates of the LA-AIDS model for rural area}

\begin{tabular}{|c|c|c|c|c|c|c|c|c|c|c|c|c|}
\hline \multirow[t]{2}{*}{ RURAL } & \multicolumn{3}{|c|}{ Choice of Fuelwood } & \multicolumn{3}{|c|}{ Choice of Kerosene } & \multicolumn{3}{|c|}{ Choice of Electricity } & \multicolumn{3}{|c|}{ Choice of LPG } \\
\hline & Low & Medium & High & Low & Medium & High & Low & Medium & High & Low & Medium & High \\
\hline Intercept & $\begin{array}{l}-0.470^{*} \\
(-13.24)\end{array}$ & \begin{tabular}{|c|}
$-0.536^{*}$ \\
$(-34.21)$
\end{tabular} & $\begin{array}{c}-0.470^{*} \\
(-14.96)\end{array}$ & \begin{tabular}{|l|}
$0.429 *$ \\
$(18.21)$
\end{tabular} & $\begin{array}{l}0.412^{*} \\
(41.21)\end{array}$ & $\begin{array}{l}0.332^{*} \\
(19.32)\end{array}$ & \begin{tabular}{|l|}
$1.096^{*}$ \\
$(30.78)$
\end{tabular} & \begin{tabular}{|l}
$1.016^{*}$ \\
$(76.72)$
\end{tabular} & \begin{tabular}{|l|}
$0.919^{*}$ \\
$(37.47)$
\end{tabular} & $\begin{array}{r}-0.056^{*} \\
(-2.60)\end{array}$ & \begin{tabular}{|r|}
$0.109 *$ \\
$(8.93)$
\end{tabular} & $\begin{array}{r}0.219^{*} \\
(7.05)\end{array}$ \\
\hline Intercept & & & & & $\begin{array}{l}0.412^{*} \\
-41.21\end{array}$ & & \begin{tabular}{|c|}
$1.096^{*}$ \\
-30.78
\end{tabular} & \begin{tabular}{|c|}
$1.016^{*}$ \\
-76.72 \\
\end{tabular} & \begin{tabular}{|l|}
$0.919 *$ \\
-37.47
\end{tabular} & $\mid \begin{array}{r}-0.056^{*} \\
(-2.60)\end{array}$ & \begin{tabular}{|c|}
$0.109 *$ \\
-8.93
\end{tabular} & \begin{tabular}{|}
$0.219 *$ \\
-7.05
\end{tabular} \\
\hline Household size & & \begin{tabular}{|c|}
$-0.012 *$ \\
$(-25.65)$ \\
\end{tabular} & & \begin{tabular}{|r|}
$0.003 *$ \\
-4.32 \\
\end{tabular} & $\begin{array}{r}0.002 * \\
-5.73 \\
\end{array}$ & \begin{tabular}{|r}
-0.001 \\
$(-1.97)$ \\
\end{tabular} & $\begin{array}{r}0.005^{*} \\
-5.23 \\
\end{array}$ & \begin{tabular}{|c|}
$0.006 *$ \\
-14.79 \\
\end{tabular} & \begin{tabular}{|r|}
$0.006 *$ \\
-7.31 \\
\end{tabular} & \begin{tabular}{|r|}
$0.001 *$ \\
-2.97 \\
\end{tabular} & \begin{tabular}{|c|}
$0.005 *$ \\
-14.71 \\
\end{tabular} & $\begin{array}{r}0.010^{*} \\
-9.83 \\
\end{array}$ \\
\hline Forward Caste & $\begin{array}{c}-0.019^{*} \\
(-2.98)\end{array}$ & \begin{tabular}{|c|}
$-0.015^{\prime}$ \\
$(-6.13)$
\end{tabular} & $\begin{array}{r}-0.047 * \\
(-9.03)\end{array}$ & $\begin{array}{c}-0.004 \\
(-1.22)\end{array}$ & $\begin{array}{c}-0.001 \\
(-0.48)\end{array}$ & $\begin{array}{r}-0.008^{*} \\
(-3.12)\end{array}$ & $\begin{array}{r}0.020^{*} \\
-3.22\end{array}$ & $\begin{array}{r}0 \\
-0.2\end{array}$ & \begin{tabular}{|r|}
0.005 \\
-1.31 \\
\end{tabular} & \begin{tabular}{|c|}
$0.003^{*}$ \\
-2.17
\end{tabular} & \begin{tabular}{|r|}
$0.016^{*}$ \\
-9.36
\end{tabular} & $\begin{array}{l}0.050^{*} \\
-10.05\end{array}$ \\
\hline $\begin{array}{l}\text { Self employed in } \\
\text { agriculturel } \\
\text { non Agriculture }\end{array}$ & & & $\begin{array}{r}0.057 * \\
-9.51\end{array}$ & $\begin{array}{l}0.011 \\
-1.69\end{array}$ & & & $\begin{array}{r}0.026^{*} \\
-2.5\end{array}$ & & $\begin{array}{c}0.003 \\
-0.69\end{array}$ & $\begin{array}{l}0.001 \\
-0.25\end{array}$ & & $\begin{array}{l}-0.059 * \\
(-10.38)\end{array}$ \\
\hline Agricultural labor & $\begin{array}{c}-0.006 \\
(-0.53)\end{array}$ & \begin{tabular}{|c|}
$0.075^{*}$ \\
-17.57 \\
\end{tabular} & \begin{tabular}{|c|}
$0.166^{*}$ \\
-14.39 \\
\end{tabular} & \begin{tabular}{|r|}
$0.018^{*}$ \\
-2.97
\end{tabular} & \begin{tabular}{|r}
0 \\
-0.04
\end{tabular} & $\begin{array}{r}0.013^{*} \\
-2.3\end{array}$ & $\begin{array}{r}-0.01 \\
(-1.02)\end{array}$ & $\begin{array}{c}-0.029^{*} \\
(-8.23)\end{array}$ & $\begin{array}{r}-0.058^{*} \\
(-6.54)\end{array}$ & \begin{tabular}{|c|}
-0.002 \\
$(-0.87)$ \\
\end{tabular} & \begin{tabular}{|c|}
$-0.046^{*}$ \\
$(-16.16)$
\end{tabular} & $\begin{array}{l}-0.122^{*} \\
(-11.04)\end{array}$ \\
\hline Other labor & $\begin{array}{c}-0.014 \\
(-1.09)\end{array}$ & \begin{tabular}{|c|}
$0.058^{*}$ \\
-10.93 \\
\end{tabular} & \begin{tabular}{|c|}
$0.137 * *$ \\
-11.25
\end{tabular} & \begin{tabular}{|c|}
0.013 \\
-1.77
\end{tabular} & $\begin{array}{r}0.013^{*} \\
-4.16\end{array}$ & $\begin{array}{r}0.040^{*} \\
-6.46\end{array}$ & $\begin{array}{l}0.001 \\
-0.08\end{array}$ & \begin{tabular}{|c|}
$-0.036^{*}$ \\
$(-8.20)$
\end{tabular} & \begin{tabular}{|c}
$-0.056^{*}$ \\
$(-5.99)$
\end{tabular} & $\begin{array}{r}0 \\
(-0.11)\end{array}$ & $-\begin{array}{r}-0.034 * \\
-9.80)\end{array}$ & $\begin{array}{l}-0.120^{*} \\
(-10.39)\end{array}$ \\
\hline South region & & \begin{tabular}{|r|}
-0.027 \\
$(-4.67)$ \\
\end{tabular} & $\begin{array}{c}-0.123 * \\
(-8.36)\end{array}$ & $\begin{array}{c}-0.019 * \\
(-2.28)\end{array}$ & $\begin{array}{c}-0.011^{*} \\
(-2.95)\end{array}$ & $\begin{array}{r}-0.01 \\
(-1.26) \\
\end{array}$ & $\begin{array}{r}0.021 \\
-1.48 \\
\end{array}$ & \begin{tabular}{|r}
$0.042^{*}$ \\
-8.59 \\
\end{tabular} & \begin{tabular}{|r|}
$0.056^{*}$ \\
-4.71 \\
\end{tabular} & 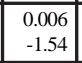 & \begin{tabular}{|c|}
-0.004 \\
$(-0.94)$
\end{tabular} & $\begin{array}{r}0.077^{*} \\
-5.16 \\
\end{array}$ \\
\hline North region & & \begin{tabular}{|c|}
$-0.020^{*}$ \\
$(-3.41)$
\end{tabular} & $\begin{array}{c}-0.074 * \\
(-4.64)\end{array}$ & \begin{tabular}{|c|}
$-0.019^{*}$ \\
$(-2.38)$
\end{tabular} & $\begin{array}{c}-0.011^{*} \\
(-3.21)\end{array}$ & $\begin{array}{r}-0.003 \\
(-0.34)\end{array}$ & $\begin{array}{r}0.034 * \\
-2.84\end{array}$ & \begin{tabular}{|r|}
$0.047 *$ \\
-9.6
\end{tabular} & \begin{tabular}{|r|}
$0.049 *$ \\
-3.97
\end{tabular} & \begin{tabular}{|c|}
-0.003 \\
$(-0.89)$
\end{tabular} & \begin{tabular}{|c|}
$-0.016^{*}$ \\
$(-3.83)$
\end{tabular} & $\begin{array}{r}0.028 \\
-1.8\end{array}$ \\
\hline East region & $\begin{array}{c}-0.003 \\
(-0.18) \\
\end{array}$ & \begin{tabular}{|c|}
-0.051 \\
$(-7.82)$ \\
\end{tabular} & \begin{tabular}{|c|}
-0.135 \\
$(-7.94)$
\end{tabular} & \begin{tabular}{|c|}
-0.008 \\
$(-0.86)$
\end{tabular} & $\begin{array}{l}0.029 \\
-7.28 \\
\end{array}$ & \begin{tabular}{|r}
0.042 \\
$(4.783$
\end{tabular} & $\begin{array}{l}0.007 \\
-0.47\end{array}$ & \begin{tabular}{|r|}
0.039 \\
-7.2 \\
\end{tabular} & $\begin{array}{r}0.06 \\
-4.51 \\
\end{array}$ & \begin{tabular}{|c|}
0.003 \\
-0.67
\end{tabular} & \begin{tabular}{|c|}
-0.017 \\
$(-3.43)$
\end{tabular} & \begin{tabular}{|c|c|c|}
0.033 \\
-1.98
\end{tabular} \\
\hline West region & $\begin{array}{r}-0.03 \\
(-1.90) \\
\end{array}$ & \begin{tabular}{|c|}
-0.0711 \\
$(-9.84)$ \\
\end{tabular} & $\begin{array}{c}-0.085^{*} \\
(-4.67)\end{array}$ & \begin{tabular}{|c|}
$-0.021^{*}$ \\
$(-2.29)$
\end{tabular} & & $\begin{array}{l}0.009 \\
-0.97 \\
\end{array}$ & $\begin{array}{r}0.057^{*} \\
-3.78\end{array}$ & \begin{tabular}{|r|}
$0.110^{*}$ \\
-18
\end{tabular} & \begin{tabular}{|r|}
$0.087 *$ \\
-5.97
\end{tabular} & \begin{tabular}{|c|}
-0.006 \\
$(-1.36)$ \\
\end{tabular} & \begin{tabular}{|r|}
$-0.023 *$ \\
$(-3.97)$
\end{tabular} & \begin{tabular}{|c|}
-0.012 \\
$(-0.65)$
\end{tabular} \\
\hline Forest & $\begin{array}{r}0.002^{*} \\
-6.63\end{array}$ & \begin{tabular}{|r|}
$0.001 *$ \\
-8.39 \\
\end{tabular} & \begin{tabular}{|r|}
$0.001 *$ \\
-6.71
\end{tabular} & $\begin{array}{c}-0.001^{*} \\
(-6.36)\end{array}$ & $\begin{array}{c}-0.001^{*} \\
(-8.68)\end{array}$ & $\begin{array}{l}0.000^{*} \\
(-2.45)\end{array}$ & $-0.001^{*}$ & \begin{tabular}{|l|}
$0.000^{*}$ \\
$(-3.57)$
\end{tabular} & \begin{tabular}{|c}
$-0.002^{*}$ \\
$(-8.96)$
\end{tabular} & \begin{tabular}{|r|}
0 \\
-0.25
\end{tabular} & & $\begin{array}{r}0 \\
-1.53\end{array}$ \\
\hline Log of expenditure & $\begin{array}{c}.193^{*} \\
-39.58\end{array}$ & \begin{tabular}{c|}
$0.183 *$ \\
-83.87
\end{tabular} & \begin{tabular}{|r|}
$0.154 *$ \\
-34.8
\end{tabular} & \begin{tabular}{|c|}
$-0.042^{*}$ \\
$(-14.30)$
\end{tabular} & $\begin{array}{l}-0.037^{*} \\
(-27.87)\end{array}$ & $\begin{array}{l}-0.030^{*} \\
(-13.48)\end{array}$ & $\begin{array}{l}-0.149 * \\
(-31.90)\end{array}$ & $\begin{array}{l}-0.131^{*} \\
(-72.38)\end{array}$ & $\begin{array}{r}-0.101 * \\
(-29.8)\end{array}$ & \begin{tabular}{|c|}
-0.002 \\
$(-1.76)$ \\
\end{tabular} & \begin{tabular}{|c|}
$-0.016^{*}$ \\
$(-10.25)$
\end{tabular} & $\begin{array}{c}-0.023 * \\
(-5.38)\end{array}$ \\
\hline Lambda & $\begin{array}{c}-0.012 \\
(-1.28)\end{array}$ & \begin{tabular}{|r|}
$-0.036^{*}$ \\
$(-3.68)$
\end{tabular} & $\begin{array}{r}0.018 \\
-1.66 \\
\end{array}$ & \begin{tabular}{|c|}
$-0.041^{*}$ \\
$(-2.31)$
\end{tabular} & & & 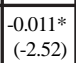 & $\begin{array}{r}0.013^{*} \\
-4.87\end{array}$ & $\begin{array}{r}0.013^{*} \\
-3.62 \\
\end{array}$ & \begin{tabular}{|r|}
$0.064 *$ \\
-3.32
\end{tabular} & \begin{tabular}{|r|}
$0.084 *$ \\
-4.97
\end{tabular} & \begin{tabular}{|c|}
-0.018 \\
$(-0.91)$
\end{tabular} \\
\hline Price Fuelwood & $\begin{array}{l}0.104^{*} \\
-18.53 \\
\end{array}$ & \begin{tabular}{|c|}
$0.096 \cdot$ \\
-42.54 \\
\end{tabular} & \begin{tabular}{|c|}
$0.059 *$ \\
-13.69 \\
\end{tabular} & & & & & & & & & \\
\hline Price Kerosene & \begin{tabular}{|c|}
-0.003 \\
$(-0.78)$ \\
\end{tabular} & \begin{tabular}{|c|}
$-0.014 *$ \\
$(-9.19)$ \\
\end{tabular} & $\begin{array}{l}-0.012^{*} \\
(-4.99)\end{array}$ & $\begin{array}{l}0.011 \\
-1.21\end{array}$ & $\begin{array}{l}0.035^{*} \\
-10.55\end{array}$ & \begin{tabular}{|r|}
$0.016^{*}$ \\
-3.14
\end{tabular} & & & & & & \\
\hline Price Electricity & $\begin{array}{l}-0.094^{*} \\
(-18.97)\end{array}$ & \begin{tabular}{|l|}
$-0.073 *$ \\
$(-42.83)$
\end{tabular} & $\begin{array}{l}-0.044^{*} \\
(-13.92)\end{array}$ & \begin{tabular}{r|}
0.01 \\
-1.99
\end{tabular} & $\begin{array}{c}-0.011^{*} \\
(-5.80)\end{array}$ & $\begin{array}{r}-0.007 * \\
(-2.11)\end{array}$ & $\begin{array}{l}0.085^{*} \\
-13.26\end{array}$ & \begin{tabular}{|l|}
$0.075^{*}$ \\
-31.53
\end{tabular} & \begin{tabular}{|l|}
$0.071 *$ \\
-14.22 \\
\end{tabular} & & & \\
\hline $\begin{array}{l}\text { Price Lpg } \\
\end{array}$ & $\begin{array}{c}0.059^{*} \\
-10.66\end{array}$ & \begin{tabular}{|r|}
$0.025^{*}$ \\
-8.41
\end{tabular} & & & & $\begin{array}{c}-0.006 \\
(-1.57)\end{array}$ & 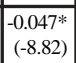 & $\begin{array}{c}-0.020^{*} \\
(-7.81)\end{array}$ & 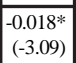 & $\begin{array}{r}0 \\
-0.01\end{array}$ & $\begin{array}{l}0.001 \\
-0.63\end{array}$ & $\begin{array}{r}0.016^{*} \\
-2.22\end{array}$ \\
\hline
\end{tabular}

Note: The figures in the parentheses are t-ratios \& ' $*$ ' denote the $5 \%$ significance level
Table 7: Estimates of the LA-AIDS model for urban area

\begin{tabular}{|c|c|c|c|c|c|c|c|c|c|c|c|c|}
\hline \multirow[t]{2}{*}{ Urban } & \multicolumn{3}{|c|}{ Choice of Fuelwood } & \multicolumn{3}{|c|}{ Choice of Kerosene } & \multicolumn{3}{|c|}{ Choice of Electricity } & \multicolumn{3}{|c|}{ Choice of LPG } \\
\hline & Low & Medium & High & Low & Medium & High & Low & Medium & High & Low & Medium & High \\
\hline Intercept & $\begin{array}{l}0.408^{*} \\
(-7.96)\end{array}$ & $\begin{array}{l}-0.405^{*} \\
-10.87)\end{array}$ & $\left\{\begin{array}{l}0.534^{*} \\
(-3.31)\end{array}\right.$ & \begin{tabular}{|c|}
$0.492^{*}$ \\
-11.43
\end{tabular} & \begin{tabular}{|c|}
$0.541^{*}$ \\
-18.24
\end{tabular} & $\begin{array}{r}0.421^{*} \\
-3.3\end{array}$ & $\begin{array}{l}1.033^{*} \\
-25.26\end{array}$ & $\mid \begin{array}{l}0.990^{*} \\
-37.57\end{array}$ & $\mid \begin{array}{r}0.751 * \\
-6.21\end{array}$ & $\begin{array}{l}0.117^{*} \\
(-3.38)\end{array}$ & $\begin{array}{l}0.125^{*} \\
(-3.54)\end{array}$ & $\begin{array}{r}0.362^{*} \\
-2.06\end{array}$ \\
\hline Household size & $\begin{array}{r}0.012 * \\
-7.85\end{array}$ & $\begin{array}{l}-0.015^{*} \\
(-11.80)\end{array}$ & )$\left(\begin{array}{l}0.021^{*} \\
(-4.37)\end{array}\right.$ & $\begin{array}{r}0 \\
(-0.34)\end{array}$ & \begin{tabular}{|l|}
$0.007 *$ \\
$(-7.34)$
\end{tabular} & $\begin{array}{l}0.011^{*} \\
(-3.05)\end{array}$ & \begin{tabular}{|l}
$0.010^{*}$ \\
-8.62
\end{tabular} & \begin{tabular}{|l|}
$0.011 *$ \\
-12.32
\end{tabular} & $\mid \begin{array}{r}0.015^{*} \\
-3.79\end{array}$ & $\begin{array}{r}.0021^{*} \\
-2.67\end{array}$ & $\begin{array}{r}0.011^{*} \\
-9.61\end{array}$ & $\begin{array}{r}0.018^{*} \\
-3.45\end{array}$ \\
\hline Forward Caste & \begin{tabular}{|r|}
-0.007 \\
-1.02 \\
\end{tabular} & $\begin{array}{c}-0.036^{*} \\
(-6.62)\end{array}$ & $\begin{array}{l}-0.031 \\
(-1.65)\end{array}$ & \begin{tabular}{|c|}
0.005 \\
-1.03 \\
\end{tabular} & $\begin{array}{r}0.001 \\
-0.2 \\
\end{array}$ & $\begin{array}{l}-0.012 \\
(-0.86)\end{array}$ & $\begin{array}{l}0.008 \\
-1.43\end{array}$ & $\begin{array}{c}-0.006 \\
(-1.50)\end{array}$ & $\left(\begin{array}{c}-0.019 \\
(-1.28)\end{array}\right.$ & $\begin{array}{l}-0.006 \\
(-1.69)\end{array}$ & $\begin{array}{r}0.041^{*} \\
-8.62\end{array}$ & $\begin{array}{r}0.063^{*} \\
-3.15\end{array}$ \\
\hline $\begin{array}{l}\text { Self employed in } \\
\text { agriculture/ } \\
\text { non Agriculture }\end{array}$ & $\begin{array}{l}0.021 \\
-1.45\end{array}$ & \begin{tabular}{|l}
-0.002 \\
$(-0.21)$
\end{tabular} & $\left\{\begin{array}{l}0.078 * \\
(-2.87)\end{array}\right.$ & $\begin{array}{l}0.008 \\
-0.75\end{array}$ & $\begin{array}{r}0.016^{*} \\
-2.41\end{array}$ & $\mid \begin{array}{l}-0.012 \\
(-0.58)\end{array}$ & $\begin{array}{l}-0.006 \\
(-0.58)\end{array}$ & $\left|\begin{array}{l}-0.001 \\
(-0.14)\end{array}\right|$ & $\begin{array}{l}0.005 \\
-0.24\end{array}$ & $\begin{array}{l}0.023 * \\
(-3.08)\end{array}$ & $\mid \begin{array}{l}-0.013 \\
(-1.63)\end{array}$ & $\begin{array}{r}0.085^{*} \\
-2.95\end{array}$ \\
\hline Agricultural labor & \begin{tabular}{|c|}
-0.024 \\
$(-1.56)$
\end{tabular} & $\begin{array}{c}-0.053^{*} \\
(-5.63)\end{array}$ & $\left\{\begin{array}{l}0.084^{*} \\
(-3.19)\end{array}\right.$ & $\begin{array}{r}.023 \\
-1.99\end{array}$ & \begin{tabular}{|r}
$0.037 *$ \\
-5.45
\end{tabular} & \begin{tabular}{|c|}
0.007 \\
-0.35 \\
\end{tabular} & $\begin{array}{r}\mid \begin{array}{r}0.01 \\
-0.83\end{array} \\
\end{array}$ & $\begin{array}{l}0.002 \\
-0.32\end{array}$ & {$\left[\begin{array}{c}-0.022 \\
(-1.06)\end{array}\right.$} & $\begin{array}{c}-0.009 \\
(-1.14)\end{array}$ & \begin{tabular}{|l|l|} 
& 0.014 \\
-1.73
\end{tabular} & $\begin{array}{r}0.100^{*} \\
-3.57\end{array}$ \\
\hline Other labor & \begin{tabular}{|r|}
$0.036^{*}$ \\
-2.42
\end{tabular} & $\begin{array}{r}0.065^{*} \\
-6.38\end{array}$ & $\begin{array}{l}0.148 * \\
-3.55\end{array}$ & $\begin{array}{l}0.002 \\
-0.19\end{array}$ & $\begin{array}{r}0.032^{*} \\
-4.43\end{array}$ & $\begin{array}{r}0.019 \\
-0.6\end{array}$ & $\begin{array}{l}-0.006 \\
(-0.55)\end{array}$ & $\mid \begin{array}{l}0.031 * \\
(-4.39)\end{array}$ & $\mid \begin{array}{l}0.076^{*} \\
(-2.28)\end{array}$ & $\begin{array}{l}0.031^{*} \\
(-4.18)\end{array}$ & $\begin{array}{l}0.066^{*} \\
(-7.48)\end{array}$ & $\begin{array}{l}0.091^{*} \\
(-2.06)\end{array}$ \\
\hline South region & $\begin{array}{l}0.052^{*} \\
(-2.23)\end{array}$ & $\begin{array}{c}-0.069^{*} \\
(-4.50)\end{array}$ & $\left\{\begin{array}{l}0.210^{*} \\
(-3.49)\end{array}\right.$ & $\begin{array}{r}0.036^{*} \\
-2.03\end{array}$ & $\begin{array}{r}0.036^{*} \\
-3.2 \\
\end{array}$ & $\begin{array}{c}-0.039 \\
(-0.77)\end{array}$ & $\begin{array}{l}0.009 \\
-0.49 \\
\end{array}$ & $\begin{array}{l}0.054 \\
(-4.95) \\
\end{array}$ & $\begin{array}{r}-0.033 \\
(-0.66)\end{array}$ & $\begin{array}{r}0.0071 \\
-0.57\end{array}$ & \begin{tabular}{|r}
$0.087 *$ \\
-6.38 \\
\end{tabular} & $\begin{array}{r}0.282^{*} \\
-4.21\end{array}$ \\
\hline North region & $\begin{array}{l}-0.023 \\
(-0.99)\end{array}$ & $\begin{array}{l}-0.023 \\
(-1.39) \\
\end{array}$ & $\begin{array}{l}-0.146 \\
(-1.99)\end{array}$ & \begin{tabular}{|l|l|}
0.011 \\
-0.62 \\
\end{tabular} & \begin{tabular}{|c|}
-0.008 \\
$(-0.62)$
\end{tabular} & $\begin{array}{l}-0.0630 \\
(-1.01)\end{array}$ & $.046 *(2$ & \begin{tabular}{|l}
$255)-0.00$ \\
$(-0.53)$
\end{tabular} & $\begin{array}{l}6-0.066 \\
(-1.19)\end{array}$ & $\begin{array}{l}0.034 * \\
(-2.70)\end{array}$ & \begin{tabular}{|r}
$0.037 *$ \\
-2.47
\end{tabular} & \begin{tabular}{|r}
$0.275^{*}$ \\
-3.33 \\
\end{tabular} \\
\hline East region & $\begin{array}{l}0.136^{*} \\
(-5.39)\end{array}$ & $\begin{array}{c}-0.161^{*} \\
(-9.01)\end{array}$ & $\left\{\begin{array}{l}0.210^{*} \\
(-2.66)\end{array}\right.$ & $\begin{array}{r}0.095^{*} \\
-4.87\end{array}$ & $\begin{array}{r}0.069^{*} \\
-5.24\end{array}$ & $\begin{array}{l}-0.001 \\
(-0.02)\end{array}$ & $\begin{array}{r}0.048^{*} \\
-2.44\end{array}$ & $\begin{array}{c}-0.004 \\
(-0.30)\end{array}$ & $\begin{array}{c}-0.041 \\
(-0.69)\end{array}$ & $\begin{array}{l}-0.008 \\
(-0.55)\end{array}$ & $\begin{array}{r}0.096^{*} \\
-5.98\end{array}$ & $\begin{array}{r}0.252^{*} \\
-2.92\end{array}$ \\
\hline West region & $\begin{array}{l}-0.027 \\
(-1.10)\end{array}$ & $\begin{array}{c}-0.029 \\
(-1.63)\end{array}$ & $\begin{array}{l}-0.011 \\
(-0.15)\end{array}$ & \begin{tabular}{|c|}
-0.017 \\
$(-0.90)$
\end{tabular} & \begin{tabular}{|c|}
-0.015 \\
$(-1.16)$
\end{tabular} & $\begin{array}{r}-0.065 \\
-1.23 \\
\end{array}$ & $\begin{array}{r}0.055^{*} \\
-2.88\end{array}$ & $\mid \begin{array}{r}0.058 * \\
-4.61 \\
\end{array}$ & $\mid \begin{array}{c}-0.052 \\
(-0.95)\end{array}$ & $\begin{array}{c}-0.012 \\
(-0.92)\end{array}$ & $\begin{array}{c}-0.014 \\
(-0.86)\end{array}$ & $\begin{array}{r}0.129 \\
-1.67\end{array}$ \\
\hline Forest & $\begin{array}{r}0.002 * \\
-4.11 \\
\end{array}$ & $\begin{array}{r}0.002 * \\
-6.24 \\
\end{array}$ & \begin{tabular}{r|r}
4 & 0 \\
4 & -0.45 \\
\end{tabular} & $\begin{array}{l}0.001 * \\
(-2.44) \\
\end{array}$ & $\begin{array}{l}0.001^{*} \\
(-7.46) \\
\end{array}$ & $\begin{array}{l}0.002^{*} \\
(-2.94)\end{array}$ & $\begin{array}{l}0.001^{*} \\
(-2.30)\end{array}$ & $\begin{array}{l}0.002^{*} \\
-11.72) \\
\end{array}$ & $\begin{array}{l}0.003 * \\
(-3.94)\end{array}$ & $\begin{array}{l}2.00 \mathrm{E}-0 \\
(-0.87)\end{array}$ & $\begin{array}{r}0.002 * \\
-8.46 \\
\end{array}$ & $\begin{array}{r}0.005^{*} \\
-4.78 \\
\end{array}$ \\
\hline log of expenditure & $\begin{array}{l}0.149^{*} \\
-23.02\end{array}$ & $\begin{array}{l}0.130^{*} \\
-26.39\end{array}$ & \begin{tabular}{|c|c|} 
& $0.136^{*}$ \\
& -7.55
\end{tabular} & $\begin{array}{l}0.029^{*} \\
(-5.67)\end{array}$ & $\begin{array}{l}0.018^{*} \\
(-4.94)\end{array}$ & $\begin{array}{l}-0.008 \\
(-0.56)\end{array}$ & $\begin{array}{l}0.125^{*} \\
(-24.7)\end{array}$ & $\mid \begin{array}{c}0.104 \\
-30.35\end{array}$ & $\mid \begin{array}{c}0.056^{*} \\
(-3.83)\end{array}$ & $\begin{array}{r}0.0054 \\
-1.52\end{array}$ & $\begin{array}{c}-0.007 \\
(-1.61)\end{array}$ & $\begin{array}{l}0.072^{*} \\
(-3.69)\end{array}$ \\
\hline Lambda & $\begin{array}{l}0.031 * \\
(-2.87)\end{array}$ & $\begin{array}{r}0.029 * \\
-5.45\end{array}$ & $\begin{array}{l}0.079 * \\
-2.56\end{array}$ & \begin{tabular}{|c|}
-0.028 \\
$(-1.27)$
\end{tabular} & $\begin{array}{r}0.075^{*} \\
-8.84\end{array}$ & $\begin{array}{r}0.066^{*} \\
-2.21\end{array}$ & $\begin{array}{l}-0.007 \\
(-0.83)\end{array}$ & $\left|\begin{array}{l}0.076 * \\
(-6.01)\end{array}\right|$ & $\left|\begin{array}{l}-0.001 \\
(-0.02)\end{array}\right|$ & $\begin{array}{l}.0656^{*} \\
-2.71\end{array}$ & $\left(\begin{array}{l}-0.029 \\
(-1.76)\end{array}\right.$ & $\begin{array}{l}-0.145 \\
(-1.64)\end{array}$ \\
\hline Price Fuelwood & $\begin{array}{r}0.060^{*} \\
-8.08\end{array}$ & $\begin{array}{r}0.045^{*} \\
-8.64\end{array}$ & \begin{tabular}{|l|l}
4 & 0.016 \\
4 & -0.75
\end{tabular} & & & & & & & & & \\
\hline Price Kerosene & $\begin{array}{l}0.045^{*} \\
(-7.14)\end{array}$ & $\begin{array}{c}-0.018^{*} \\
(-4.71)\end{array}$ & $\left\{\begin{array}{l}-0.007 \\
(-0.42)\end{array}\right.$ & $\begin{array}{r}0.127^{*} \\
-7.34\end{array}$ & \begin{tabular}{|l|l}
$0.158 *$ \\
-14.31 \\
\end{tabular} & \begin{tabular}{|r|r|} 
& .081 \\
-1.79
\end{tabular} & & & & & & \\
\hline Price Electricity & $\begin{array}{l}0.034^{*} \\
(-6.81)\end{array}$ & $\begin{array}{l}-0.035^{*} \\
-10.63)\end{array}$ & $\left\{\begin{array}{l}-0.009 \\
(-0.60)\end{array}\right.$ & $\begin{array}{l}-0.001 \\
(-0.10)\end{array}$ & $\begin{array}{l}0.014 * \\
(-3.26)\end{array}$ & $\begin{array}{l}-0.021 \\
(-1.05)\end{array}$ & $\begin{array}{r}0.009 \\
-1.54 \\
\end{array}$ & $\begin{array}{r}0.010^{*} \\
-2.28 \\
\end{array}$ & \begin{tabular}{|c|c}
0.035 \\
-1.77
\end{tabular} & & & \\
\hline Price LPG & $\begin{array}{c}-0.01 \\
(-0.60)\end{array}$ & $\begin{array}{c}-0.038^{*} \\
(-3.34)\end{array}$ & $\left(\begin{array}{l}-0.049 \\
(-1.12)\end{array}\right.$ & $\begin{array}{l}0.017 \\
-1.41\end{array}$ & $\begin{array}{r}0.031 * \\
-3.82\end{array}$ & $\begin{array}{l}0.043 \\
-1.27\end{array}$ & $\begin{array}{l}.001 \\
-0.09\end{array}$ & $\begin{array}{c}-0.012 \\
(-1.50)\end{array}$ & $\mid \begin{array}{c}-0.049 \\
(-1.40)\end{array}$ & $\begin{array}{l}-0.009 \\
(-1.01)\end{array}$ & $\begin{array}{l}0.018 \\
-1.84\end{array}$ & $\begin{array}{c}0.055 \\
-1.19\end{array}$ \\
\hline
\end{tabular}

Note: The figures in the parentheses are t-ratios \& ' $*$ ’ denote the $5 \%$ significance level 
Table 8: Chow Statistics for different income cut-off points

\begin{tabular}{|c|c|c|c|c|c|}
\hline $\begin{array}{c}\text { Cut-Off Point } \\
\text { (Per Capita Income) }\end{array}$ & Sector & $\begin{array}{c}\text { Numerator } \\
\text { Degrees Of } \\
\text { Freedom }\end{array}$ & $\begin{array}{c}\text { Denominator } \\
\text { Degrees Of } \\
\text { Freedom }\end{array}$ & F-Test & Pr> F \\
\hline 328 & Rural & 48 & 27358 & 4.91 & $<0.0001$ \\
774 & Rural & 48 & 27358 & 21.31 & $<0.0001$ \\
455 & Urban & 48 & 9422 & 3.31 & $<0.0001$ \\
1421 & Urban & 48 & 9422 & 8.80 & $<0.0001$ \\
\hline
\end{tabular}

Table 9: Estimated uncompensated (Marshallian) own-price elasticities for rural and urban areas by expenditure group

\begin{tabular}{l|r|r|r|r|r|r}
\hline \multirow{4}{*}{ Fuelwood } & \multicolumn{3}{|c|}{ Rural } & \multicolumn{3}{c}{ Urban } \\
\cline { 2 - 7 } & \multicolumn{1}{|c|}{ Low } & \multicolumn{1}{c|}{ Medium } & \multicolumn{1}{c|}{ High } & \multicolumn{1}{c}{ Low } & \multicolumn{1}{c}{ Medium } & \multicolumn{1}{c}{ High } \\
\hline \multirow{4}{*}{ Kerosene } & $-1.05^{*}$ & $-1.03^{*}$ & $-1.03^{*}$ & $-1.04^{*}$ & $-1.02^{*}$ & $-1.05^{*}$ \\
& $(-0.009)$ & $(-0.004)$ & $(-0.008)$ & $(-0.013)$ & $(-0.011)$ & $(-0.046)$ \\
& $-0.84^{*}$ & $-0.75^{*}$ & $-0.86^{*}$ & $-0.18^{*}$ & $-0.21^{*}$ & -0.14 \\
Electricity & $(-0.049)$ & $(-0.016)$ & $(-0.027)$ & $(-0.069)$ & $(-0.038)$ & $(-0.169)$ \\
& $-0.59^{*}$ & -0.66 & $-0.72^{*}$ & $-0.85^{*}$ & $-0.87^{*}$ & $-0.91^{*}$ \\
LPG & $(-0.021)$ & $(-0.007)$ & $(-0.014)$ & $(-0.014)$ & $(-0.010)$ & $(-0.031)$ \\
& $-1.00^{*}$ & $-0.98^{*}$ & $-0.97^{*}$ & $-1.05^{*}$ & $-1.01^{*}$ & $-0.92^{*}$ \\
& $(-0.003)$ & $(-0.005)$ & $(-0.015)$ & $(-0.015)$ & $(-0.018)$ & $(-0.075)$ \\
\hline
\end{tabular}

Note: The figures in the parentheses are standard errors
Table 10: Estimated compensated price elasticities by income groups for rural and urban households ${ }^{5}$

\begin{tabular}{|c|c|c|c|c|c|c|c|c|c|}
\hline & \multicolumn{4}{|c|}{ Low income } & & \multicolumn{4}{|c|}{ Low income } \\
\hline & \multicolumn{4}{|c|}{ Rural } & & \multicolumn{4}{|c|}{ Urban } \\
\hline & Fuelwood & Kerosene & \begin{tabular}{|l|} 
Electricity \\
\end{tabular} & LPG & & Fuelwood & Kerosene & Electricity & LPG \\
\hline Fuelwood & $\begin{array}{l}-0.126^{*} \\
(-0.010)\end{array}$ & $\begin{array}{r}0.239 * \\
(-0.007)\end{array}$ & $\begin{array}{r}0.191 * \\
(-0.007)\end{array}$ & $\begin{array}{c}0.596^{*} \\
(-0.010)\end{array}$ & Fuelwood & $\begin{array}{r}-0.292^{*} \\
-0.014\end{array}$ & $\begin{array}{r}0.244 \\
-0.013\end{array}$ & $\begin{array}{r}0.2 \\
-0.011\end{array}$ & $\begin{array}{r}0.661 \\
-0.029\end{array}$ \\
\hline Kerosene & $\begin{array}{r}0.712^{*} \\
(-0.0157)\end{array}$ & $\begin{array}{l}-0.630^{*} \\
(-0.049)\end{array}$ & $\begin{array}{r}0.361^{*} \\
(-0.020)\end{array}$ & $\begin{array}{r}0.470^{*} \\
(-0.014)\end{array}$ & Kerosene & $\begin{array}{l}0.470^{*} \\
-0.021\end{array}$ & $\begin{array}{l}0.112 \\
-0.07\end{array}$ & $\begin{array}{r}0.453 \\
-0.023\end{array}$ & $\begin{array}{r}0.604 \\
-0.041\end{array}$ \\
\hline Electricity & $\begin{array}{r}0.440^{*} \\
(-0.017)\end{array}$ & $\begin{array}{r}0.279 * \\
(-0.016)\end{array}$ & $\begin{array}{l}-0.421{ }^{*} \\
(-0.021)\end{array}$ & $\begin{array}{r}0.378^{*} \\
(-0.018)\end{array}$ & Electricity & $\begin{array}{l}0.474 * \\
-0.014\end{array}$ & $\begin{array}{r}0.348 \\
-0.018\end{array}$ & $\begin{array}{l}-0.581 \\
-0.015\end{array}$ & $\begin{array}{r}0.586 \\
-0.032\end{array}$ \\
\hline \multirow[t]{3}{*}{ LPG } & $\begin{array}{c}0.843^{*} \\
(-0.011)\end{array}$ & $\begin{array}{r}0.223 * \\
(-0.007)\end{array}$ & $\begin{array}{r}0.232^{*} \\
(-0.011)\end{array}$ & $\begin{array}{c}-0.484 * \\
(-0.003)\end{array}$ & LPG & $\begin{array}{l}0.653^{*} \\
-0.028\end{array}$ & $\begin{array}{r}0.309 \\
-0.021\end{array}$ & $\begin{array}{r}0.391 \\
-0.021\end{array}$ & $\begin{array}{l}-0.447 \\
-0.015\end{array}$ \\
\hline & \multicolumn{4}{|c|}{ Medium income } & & \multicolumn{4}{|c|}{ Medium income } \\
\hline & Fuelwood & Kerosene & Electricity & LPG & & Fuelwood & Kerosene & Electricity & LPG \\
\hline Fuelwood & $\begin{array}{r}-0.178^{*} \\
-0.004\end{array}$ & $\begin{array}{c}0.199^{*} \\
-0.003\end{array}$ & $\begin{array}{c}0.230^{*} \\
-0.004\end{array}$ & $\begin{array}{l}0.549 * \\
-0.005 \\
\end{array}$ & Fuelwood & $\begin{array}{r}-0.395^{*} \\
-0.012\end{array}$ & $\begin{array}{r}0.257 * \\
-0.01\end{array}$ & $\begin{array}{c}0.358^{*} \\
-0.008\end{array}$ & $\begin{array}{c}0.536^{*} \\
-0.023\end{array}$ \\
\hline Kerosene & $\begin{array}{r}0.610^{*} \\
-0.008\end{array}$ & $\begin{array}{r}-0.568^{*} \\
-0.016\end{array}$ & $\begin{array}{r}0.302^{*} \\
-0.009\end{array}$ & $\begin{array}{r}0.483 * \\
-0.01\end{array}$ & Kerosene & $\begin{array}{c}0.431 * \\
-0.014\end{array}$ & $\begin{array}{l}0.075 * \\
-0.038\end{array}$ & $\begin{array}{l}0.382^{*} \\
-0.016\end{array}$ & $\begin{array}{l}0.648^{*} \\
-0.029\end{array}$ \\
\hline Electricity & $\begin{array}{l}0.450 * \\
-0.006 \\
\end{array}$ & $\begin{array}{l}0.193^{*} \\
-0.006 \\
\end{array}$ & $\begin{array}{r}-0.456^{*} \\
-0.007 \\
\end{array}$ & $\begin{array}{r}0.447 * \\
-0.008 \\
\end{array}$ & Electricity & $\begin{array}{r}0.398^{*} \\
-0.008 \\
\end{array}$ & $\begin{array}{r}0.254^{*} \\
-0.011 \\
\end{array}$ & $\begin{array}{r}-0.548^{*} \\
-0.011 \\
\end{array}$ & $\begin{array}{r}0.501 * \\
-0.018 \\
\end{array}$ \\
\hline \multirow[t]{3}{*}{ LPG } & $\begin{array}{l}0.715 * \\
-0.006\end{array}$ & $\begin{array}{l}0.205 * \\
-0.004\end{array}$ & $\begin{array}{l}0.298^{*} \\
-0.005\end{array}$ & $\begin{array}{r}-0.489 * \\
-0.005\end{array}$ & LPG & $\begin{array}{l}0.489 * \\
-0.021\end{array}$ & $\begin{array}{c}0.352 * \\
-0.016\end{array}$ & $\begin{array}{l}0.410^{*} \\
-0.016\end{array}$ & $\begin{array}{r}-0.513^{*} \\
-0.019\end{array}$ \\
\hline & \multicolumn{4}{|c|}{ High Income } & & \multicolumn{4}{|c|}{ High Income } \\
\hline & Fuelwood & Kerosene & \begin{tabular}{|l|} 
Electricity \\
\end{tabular} & LPG & & Fuelwood & Kerosene & \begin{tabular}{|l} 
Electricity \\
\end{tabular} & LPG \\
\hline Fuelwood & $\begin{array}{c}-0.330^{*} \\
(-0.009)\end{array}$ & $\begin{array}{r}0.174^{*} \\
(-0.006)\end{array}$ & $\begin{array}{r}0.274^{*} \\
(-0.008)\end{array}$ & $\begin{array}{r}0.520^{*} \\
(-0.014)\end{array}$ & Fuelwood & $\begin{array}{c}-0.584 * \\
-0.047\end{array}$ & $\begin{array}{c}0.290^{*} \\
-0.032\end{array}$ & $\begin{array}{c}0.463^{*} \\
-0.031\end{array}$ & $\begin{array}{c}0.507 * \\
-0.091\end{array}$ \\
\hline Kerosene & $\begin{array}{c}0.495 * \\
(-0.013)\end{array}$ & $\begin{array}{c}-0.705 * \\
(-0.027) \\
\end{array}$ & $\begin{array}{r}0.373^{*} \\
(-0.019)\end{array}$ & $\begin{array}{r}0.458^{*} \\
(-0.021)\end{array}$ & Kerosene & $\begin{array}{l}0.547 * \\
-0.056\end{array}$ & $\begin{array}{r}0.082 \\
-0.169\end{array}$ & $\begin{array}{l}0.318 * \\
-0.076\end{array}$ & $\begin{array}{l}1.102 * \\
-0.118\end{array}$ \\
\hline Electricity & $\begin{array}{r}0.389 * \\
(-0.001) \\
(\end{array}$ & $\begin{array}{r}0.186^{*} \\
(-0.001)\end{array}$ & $\begin{array}{c}-0.443^{*} \\
(-0.014)\end{array}$ & $\begin{array}{r}0.466^{*} \\
(-0.016)\end{array}$ & Electricity & $\begin{array}{c}0.321 * \\
-0.022 \\
\end{array}$ & $\begin{array}{l}0.117 * \\
-0.029\end{array}$ & $\begin{array}{r}-0.444 * \\
-0.033 \\
\end{array}$ & $\begin{array}{r}0.228^{*} \\
-0.047\end{array}$ \\
\hline LPG & $\begin{array}{r}0.565^{*} \\
(-0.016)\end{array}$ & $\begin{array}{r}0.175^{*} \\
(-0.009)\end{array}$ & $\begin{array}{c}0.356^{*} \\
(-0.013)\end{array}$ & $\begin{array}{c}-0.512^{*} \\
(-0.015)\end{array}$ & LPG & $\begin{array}{r}0.384 * \\
-0.07\end{array}$ & $\begin{array}{l}0.443 * \\
-0.049\end{array}$ & $\begin{array}{l}0.250^{*} \\
-0.052\end{array}$ & $\begin{array}{r}-0.519 * \\
-0.076\end{array}$ \\
\hline
\end{tabular}

5 The table should be read from left and up. For example, for low-income rural households a one percent increase in price of kerosene would lead to a 0.712 percent increase in fuelwood consumption. 
Table 11: Expenditure elasticities for rural and urban areas

by income groups

\begin{tabular}{|c|c|c|c|c|c|c|c|c|c|}
\hline & \multicolumn{4}{|c|}{ Elasticises LA/AIDS } & \multirow{2}{*}{\begin{tabular}{|c|c|} 
Engel \\
elasticises
\end{tabular}} & \multicolumn{4}{|c|}{ Integrated Elasticises } \\
\hline Rural & Fuelwood & Kerosene & Electricity & LPG & & Fuelwood & Kerosene & Electricity & LPG \\
\hline Low & $\begin{array}{l}1.261 * \\
-0.007\end{array}$ & $\begin{array}{l}0.837^{*} \\
-0.012\end{array}$ & $\begin{array}{l}0.533^{*} \\
-0.015\end{array}$ & $\begin{array}{l}0.994 * \\
-0.003\end{array}$ & 0.655 & 0.792 & 0.6 & 0.375 & 0.657 \\
\hline Medium & $\begin{array}{l}1.278^{*} \\
-0.003\end{array}$ & $\begin{array}{l}0.840 * \\
-0.006\end{array}$ & $\begin{array}{l}0.619^{*} \\
-0.005\end{array}$ & $\begin{array}{l}0.960^{* *} \\
-0.003\end{array}$ & 0.792 & 1.012 & 0.665 & 0.49 & 0.76 \\
\hline High & $\begin{array}{l}1.313^{*} \\
-0.008\end{array}$ & $\begin{array}{l}0.854^{*} \\
-0.012\end{array}$ & $\begin{array}{r}0.725 * * \\
-0.009\end{array}$ & $\begin{array}{c}0.926^{*} \\
-0.009\end{array}$ & 0.604 & 0.761 & 0.564 & 0.399 & 0.606 \\
\hline Urban & Fuelwood & Kerosene & Electricity & LPG & & Fuelwood & Kerosene & Electricity & LPG \\
\hline Low & $\begin{array}{l}1.260^{*} \\
-0.011\end{array}$ & $\begin{array}{l}0.934 * \\
-0.017\end{array}$ & $\begin{array}{l}0.661^{*} \\
-0.013\end{array}$ & $\begin{array}{l}1.003 * \\
-0.006\end{array}$ & 0.986 & 1.242 & 0.921 & 0.652 & 0.989 \\
\hline Medium & $\begin{array}{r}1.303 * \\
-0.01\end{array}$ & $\begin{array}{l}0.977^{*} \\
-0.013\end{array}$ & $\begin{array}{l}0.751 * \\
-0.008\end{array}$ & $\begin{array}{l}0.940^{*} \\
-0.008\end{array}$ & 0.7 & 0.912 & 0.684 & 0.526 & 0.658 \\
\hline High & $\begin{array}{l}1.272 * \\
-0.032\end{array}$ & $\begin{array}{l}1.182 * \\
-0.044\end{array}$ & $\begin{array}{c}0.895^{*} \\
-0.017\end{array}$ & $\begin{array}{l}0.835^{*} \\
-0.027\end{array}$ & 0.665 & 0.846 & 0.787 & 0.596 & 0.556 \\
\hline
\end{tabular}

Note: The figures in the parentheses are standard errors.
Figure 1. Choice of main fuel by different expenditure classes (Rural areas)

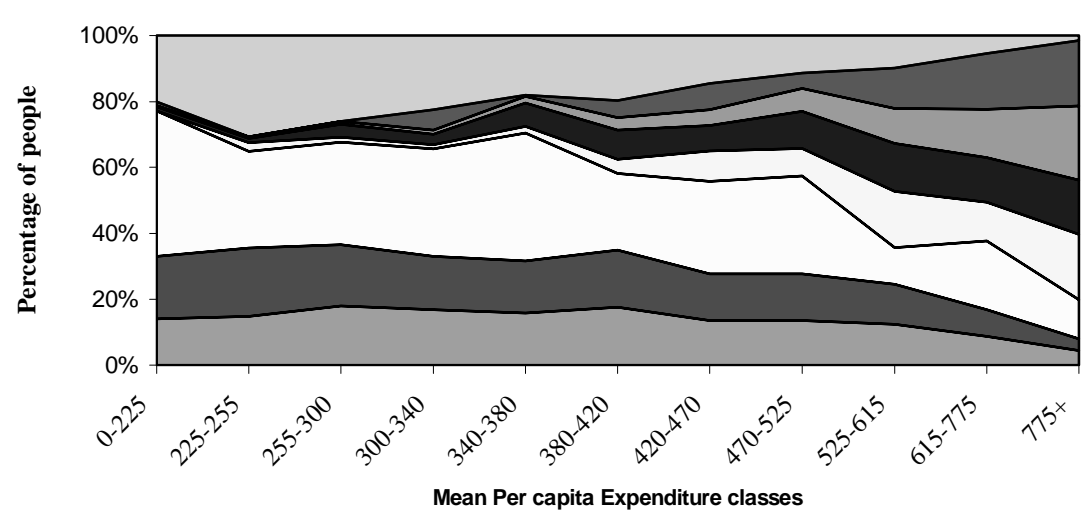

$\square$ dung cake $\quad \square$ Fire wood \& chips $\quad \square$ Coke coal charcoal $\square$ Gobar gas

$\begin{array}{lll}\square \text { kerosene } & \text { LPG } & \end{array}$

Figure 2. Choice of main fuel by different expenditure classes (urban areas)

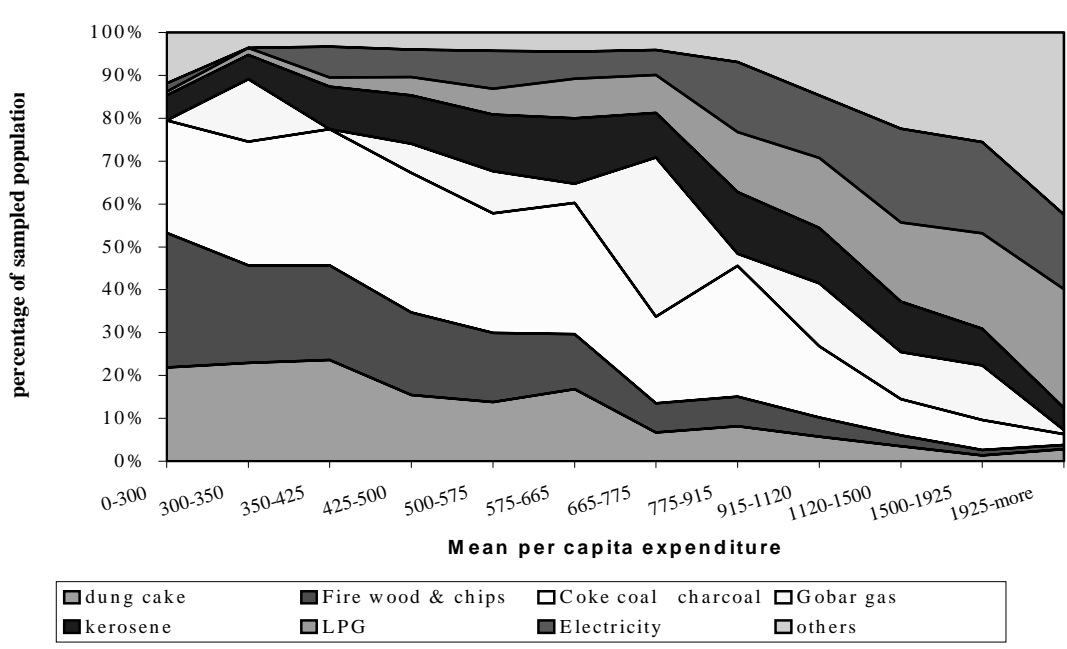


Figure 3. Expenditure elasticities for different fuels (Rural India)

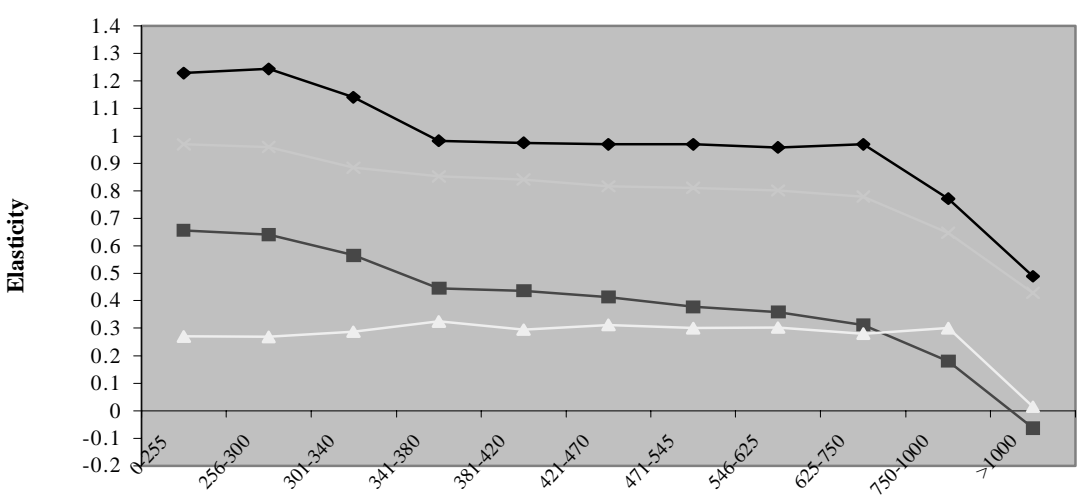

Expenditure claases

$\rightarrow \bullet$ Fuelwood $\rightarrow$ Kerosene $\quad$ Electricity $\nrightarrow$ LPG

Figure 4. Expenditure elasticities for different expenditure classes (Urban India)

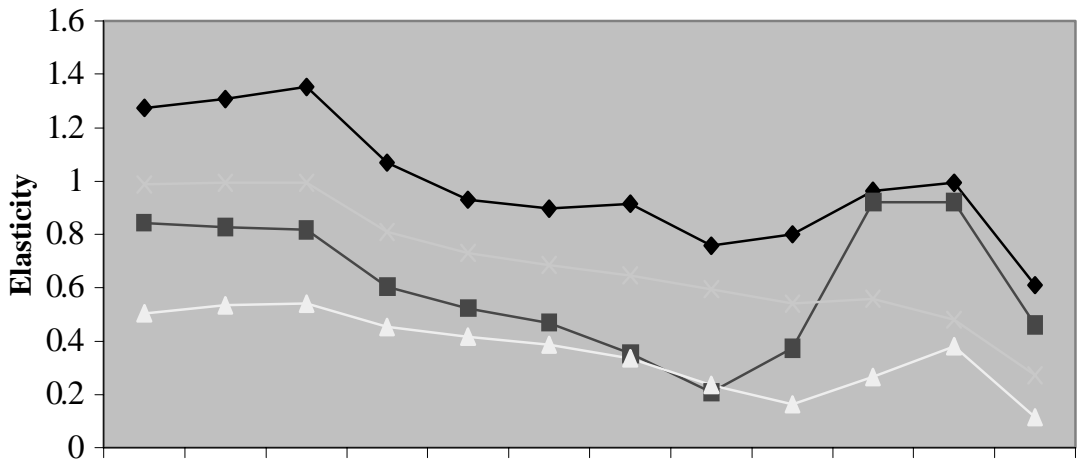

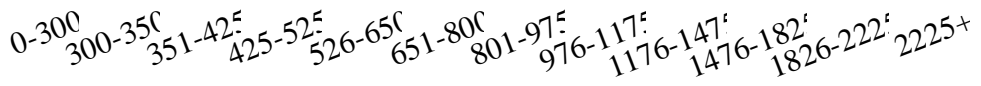

\section{Expenditure classes}

fuelwood - - Kerosene Electricity - LPG

\section{Appendix 1}

Table A1. Estimated uncompensated price elasticities by income groups for rural and urban households ${ }^{6}$

\begin{tabular}{|c|c|c|c|c|c|c|c|c|}
\hline & \multicolumn{4}{|c|}{ Low income } & \multicolumn{4}{|c|}{ Low income } \\
\hline & \multicolumn{4}{|c|}{ Rural } & \multicolumn{4}{|c|}{ Urban } \\
\hline & Fuelwood & Kerosene & Electricity & LPG & Fuelwood & Kerosene & Electricity & LPG \\
\hline Fuelwood & $\begin{array}{r}-1.05^{*} \\
(-0.009)\end{array}$ & $\begin{array}{c}-0.071^{*} \\
(-0.005)\end{array}$ & $\begin{array}{c}-0.209^{*} \\
(-0.007)\end{array}$ & $\begin{array}{c}-0.057^{*} \\
(-0.008)\end{array}$ & $\begin{array}{r}-1.04^{*} \\
(-0.013)\end{array}$ & $\begin{array}{c}-0.144 * \\
(-0.011)\end{array}$ & $\begin{array}{c}-0.185^{*} \\
(-0.009)\end{array}$ & $\begin{array}{c}-0.097 * \\
(-0.028)\end{array}$ \\
\hline Kerosene & $\begin{array}{r}0.098^{*} \\
(-0.015)\end{array}$ & $\begin{array}{c}-0.835 * \\
(-0.049)\end{array}$ & $\begin{array}{r}0.095^{*} \\
(-0.019)\end{array}$ & $\begin{array}{r}0.037^{*} \\
(-0.014)\end{array}$ & $\begin{array}{c}-0.085^{*} \\
(-0.021)\end{array}$ & $\begin{array}{c}-0.176^{*} \\
(-0.069)\end{array}$ & $\begin{array}{r}0.078^{*} \\
(-0.022)\end{array}$ & $\begin{array}{r}0.042 \\
(-0.041)\end{array}$ \\
\hline Electricity & $\begin{array}{r}0.049 * \\
(-0.016)\end{array}$ & $\begin{array}{r}0.148 * \\
(-0.015)\end{array}$ & $\begin{array}{c}-0.590^{*} \\
(-0.021)\end{array}$ & $\begin{array}{r}0.102^{*} \\
(-0.017)\end{array}$ & $\begin{array}{r}0.081^{*} \\
(-0.013)\end{array}$ & $\begin{array}{r}0.144 * \\
(-0.017)\end{array}$ & $\begin{array}{c}-0.846^{*} \\
(-0.014)\end{array}$ & $\begin{array}{r}0.188^{*} \\
(-0.032)\end{array}$ \\
\hline \multirow[t]{3}{*}{ LPG } & $\begin{array}{r}0.115^{*} \\
(-0.011)\end{array}$ & $\begin{array}{c}-0.021 * \\
(-0.007)\end{array}$ & $\begin{array}{c}-0.084^{*} \\
(-0.011)\end{array}$ & $\begin{array}{c}-0.998^{*} \\
(-0.003)\end{array}$ & $\begin{array}{r}0.057 * \\
(-0.028)\end{array}$ & $\begin{array}{c}-0.0001 \\
(-0.021)\end{array}$ & $\begin{array}{r}-0.012 \\
(-0.021)\end{array}$ & $\begin{array}{r}-1.05^{*} \\
(-0.015)\end{array}$ \\
\hline & \multicolumn{4}{|c|}{ Middle Income } & \multicolumn{4}{|c|}{ Middle Income } \\
\hline & Fuelwood & Kerosene & Electricity & LPG & Fuelwood & Kerosene & Electricity & LPG \\
\hline Fuelwood & $\begin{array}{l}-1.026^{*} \\
(-0.004)\end{array}$ & $\begin{array}{c}-0.078^{*} \\
(-0.003)\end{array}$ & $\begin{array}{c}-0.203^{*} \\
(-0.003)\end{array}$ & $\begin{array}{c}-0.102^{*} \\
(-0.005)\end{array}$ & $\begin{array}{l}-1.025^{*} \\
(-0.011)\end{array}$ & $\begin{array}{c}-0.119 * \\
(-0.008)\end{array}$ & $\begin{array}{c}-0.208 * \\
(-0.007)\end{array}$ & $\begin{array}{c}-0.155^{*} \\
(-0.023)\end{array}$ \\
\hline Kerosene & $\begin{array}{r}0.052^{*} \\
(-0.008)\end{array}$ & $\begin{array}{c}-0.749 * \\
(-0.016)\end{array}$ & $\begin{array}{r}0.017 \\
(-0.009)\end{array}$ & $\begin{array}{l}0.0551^{*} \\
(-0.009)\end{array}$ & $\begin{array}{c}-0.042^{*} \\
(-0.014)\end{array}$ & $\begin{array}{c}-0.208 * \\
(-0.038)\end{array}$ & $\begin{array}{c}-0.043^{*} \\
(-0.015)\end{array}$ & $\begin{array}{r}0.129^{*} \\
(-0.028)\end{array}$ \\
\hline Electricity & $\begin{array}{c}0.040^{*} \\
(-0.005)\end{array}$ & $\begin{array}{r}0.059^{*} \\
(-0.006)\end{array}$ & $\begin{array}{r}-0.66 \\
(-0.007)\end{array}$ & $\begin{array}{r}0.131^{*} \\
(-0.007)\end{array}$ & $\begin{array}{r}0.035^{*} \\
(-0.008)\end{array}$ & $\begin{array}{r}0.037 * \\
(-0.010)\end{array}$ & $\begin{array}{c}-0.874^{*} \\
(-0.010)\end{array}$ & $\begin{array}{r}0.102^{*} \\
(-0.018)\end{array}$ \\
\hline \multirow[t]{3}{*}{ LPG } & $\begin{array}{c}0.078^{*} \\
(-0.006)\end{array}$ & $\begin{array}{r}-0.003 \\
(-0.004)\end{array}$ & $\begin{array}{r}-0.028 \\
(-0.005)\end{array}$ & $\begin{array}{c}-0.978^{*} \\
(-0.005)\end{array}$ & $\begin{array}{r}0.034^{*} \\
(-0.021)\end{array}$ & $\begin{array}{c}0.081^{*} \\
(-0.015)\end{array}$ & $\begin{array}{r}0.0014 \\
(-0.015)\end{array}$ & $\begin{array}{r}-1.01 * \\
(-0.018)\end{array}$ \\
\hline & \multicolumn{4}{|c|}{ High Income } & \multicolumn{4}{|c|}{ High Income } \\
\hline & Fuelwood & Kerosene & Electricity & LPG & Fuelwood & Kerosene & Electricity & LPG \\
\hline Fuelwood & $\begin{array}{r}-1.03^{*} \\
(-0.008)\end{array}$ & $\begin{array}{c}-0.072^{*} \\
(-0.0045)\end{array}$ & $\begin{array}{c}-0.218^{*} \\
(-0.006)\end{array}$ & $\begin{array}{c}-0.123^{*} \\
(-0.014)\end{array}$ & $\begin{array}{l}-1.046^{*} \\
(-0.046)\end{array}$ & $\begin{array}{r}0.045 \\
(-0.029)\end{array}$ & $\begin{array}{c}-0.203^{*} \\
(-0.028)\end{array}$ & $\begin{array}{c}-0.102^{*} \\
(-0.090)\end{array}$ \\
\hline Kerosene & $\begin{array}{c}0.040^{*} \\
(-0.013)\end{array}$ & $\begin{array}{c}-0.865 * \\
(-0.027)\end{array}$ & $\begin{array}{r}0.053^{*} \\
(-0.018)\end{array}$ & $\begin{array}{r}0.040^{*} \\
(-0.020)\end{array}$ & $\begin{array}{r}0.118^{*} \\
(-0.055)\end{array}$ & $\begin{array}{r}-0.145 \\
(-0.169)\end{array}$ & $\begin{array}{c}-0.301 * \\
(-0.075)\end{array}$ & $\begin{array}{r}0.536^{*} \\
(-0.118)\end{array}$ \\
\hline Electricity & $\begin{array}{r}0.003 \\
(-0.009)\end{array}$ & $\begin{array}{l}0.0507 * \\
(-0.009)\end{array}$ & $\begin{array}{c}-0.715^{*} \\
(-0.014)\end{array}$ & $\begin{array}{r}0.110^{*} \\
(-0.016)\end{array}$ & $\begin{array}{r}-0.004 \\
(-0.020)\end{array}$ & $\begin{array}{r}-0.055 \\
(-0.028)\end{array}$ & $\begin{array}{l}-0.912^{*} \\
(-0.031)\end{array}$ & $\begin{array}{c}-0.200^{*} \\
(-0.046)\end{array}$ \\
\hline LPG & $\begin{array}{r}0.072 * \\
(-0.015)\end{array}$ & $\begin{array}{r}0.002 \\
(-0.008)\end{array}$ & $\begin{array}{r}0.009 \\
(-0.012)\end{array}$ & $\begin{array}{c}-0.966^{*} \\
(-0.015)\end{array}$ & $\begin{array}{r}0.081 \\
(-0.069)\end{array}$ & $\begin{array}{r}0.282^{*} \\
(-0.047)\end{array}$ & $\begin{array}{c}-0.188^{*} \\
(-0.050)\end{array}$ & $\begin{array}{c}-0.919^{*} \\
(-0.075)\end{array}$ \\
\hline
\end{tabular}

${ }^{6}$ The table should be read from left and up. For example, for low income rural households a one percent increase in price of kerosene would lead to a 0.712 percent increase in fuelwood consumption. 